\title{
Review Article \\ The Role of Microglia and Matrix Metalloproteinases Involvement in Neuroinflammation and Gliomas
}

\author{
Helen Könnecke ${ }^{1}$ and Ingo Bechmann ${ }^{2}$ \\ ${ }^{1}$ Clinic of Neurology, University of Zurich, Frauenklinikstrasse 26, 8091 Zurich, Switzerland
}

${ }^{2}$ Institute of Anatomy, University of Leipzig, Liebigstrasse 13, 04103 Leipzig, Germany

Correspondence should be addressed to Helen Könnecke; helen.koennecke@usz.ch

Received 10 May 2013; Accepted 20 June 2013

Academic Editor: Wolfgang J. Streit

Copyright ( 2013 H. Könnecke and I. Bechmann. This is an open access article distributed under the Creative Commons Attribution License, which permits unrestricted use, distribution, and reproduction in any medium, provided the original work is properly cited.

\begin{abstract}
Matrix metalloproteinases (MMPs) are involved in the pathogenesis of neuroinflammatory diseases (such as multiple sclerosis) as well as in the expansion of malignant gliomas because they facilitate penetration of anatomical barriers (such as the glia limitans) and migration within the neuropil. This review elucidates pathomechanisms and summarizes the current knowledge of the involvement of MMPs in neuroinflammation and glioma, invasion highlighting microglia as major sources of MMPs. The induction of expression, suppression, and multiple pathways of function of MMPs in these scenarios will also be discussed. Understanding the induction and action of MMPs might provide valuable information and reveal attractive targets for future therapeutic strategies.
\end{abstract}

\section{Barriers from Blood to Brain}

Influx of inflammatory cells into the neuropil is a hallmark of neuroinflammation (e.g., in multiple sclerosis (MS) [1], and respective mechanisms have been studied extensively in experimental autoimmune encephalomyelitis (EAE), an animal model for multiple sclerosis. Initially, leukocytes migrate across vascular walls and accumulate in the perivascular space. This perivascular "cuffing" [2], however, is only the first step in neuroinflammation because immune cells need to pass the glia limitans and its basement membrane to reach the parenchyma proper in a second, differentially regulated step [3]. While the endothelium does not provide an insurmountable barrier for activated $\mathrm{T}$ and $\mathrm{B}$ cells under certain (experimental) conditions $[4,5]$, the glia limitans and the parenchymal basal lamina represent more strictly regulated, secondary barriers [3]. Importantly, clinical symptoms only occur after the penetration of the parenchymal basal lamina (BM), which is formed by a variety of organized extracellular matrix (ECM) components build by astrocytic endfeet of the glia limitans.

There is strong evidence that inducible proteases, known as matrix metalloproteinases (MMPs), are involved in the second step of neuroinflammation [3, 6-10]. The unique features of different, highly specialized, basal laminae rely on their major constituents: collagen IV and laminin predominant are whereas collagen type $\mathrm{V}$, proteoglycans, and glycoproteins are additional constituents [11]. Collagen types IV and V are, unlike other collagens, structurally organized in a nonfibrillar, multilayer network that is resistant to nonspecific proteolytic degradation. Noteworthy is the existence of different laminin isoforms in the specialized basement membrane (BM) of the vessel and the BM of the glia limitans. While the vascular BM exhibits laminin 8 and laminin 10 , the $\mathrm{BM}$ of the glia limitans is characterized by laminin 1 and laminin 2 [12]. Dystroglycan is a transmembrane receptor that anchors astrocyte endfeet to the parenchymal BM [13-15] via high-affinity interactions with laminin 1 and 2. Dystroglycan was identified as a specific substrate of MMP2 and MMP-9 [16]. Thus MMPs, secreted by juxtavascular microglia, might control the ECM composition, and as a consequence MMPs are involved in the integrity and function of the glia limitans.

\section{The MMP Family}

The MMPs are a family of zinc containing endoproteinases that share structural domains but differ in substrate specificity, cellular sources, and inducibility. The major function 


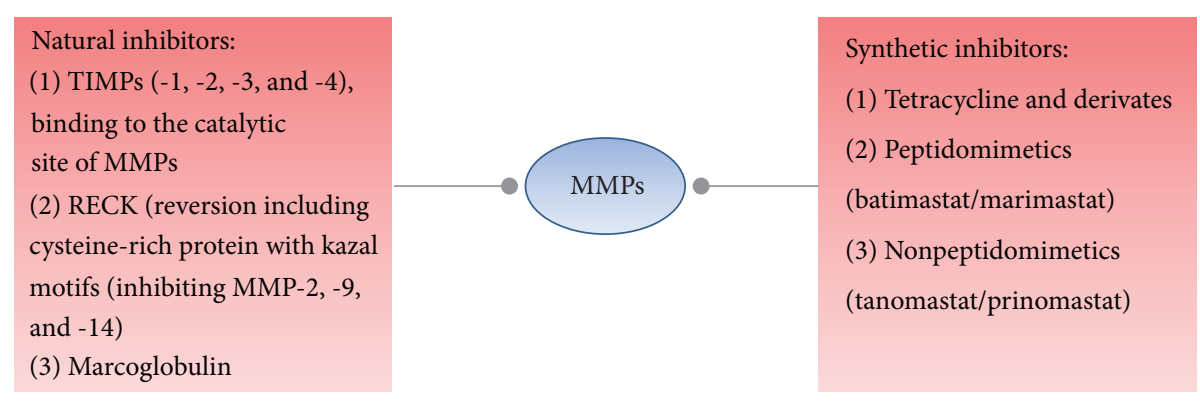

FIGURE 1: MMP inhibition is possible by targeted natural as well as synthetic inhibitors. References: Visse and Nagase [18]; Oh et al. [201]; Coussens et al. [202]; Overall and López-Otín [203].

is the degradation and remodeling of all components of the ECM. As a group of more than 20 structurally related enzymes, they can be divided according to their substrate affinity profile: gelatinases (MMP-2 and -9), interstitial collagenases (MMP-1, -8, and -13), broad-specific stromelysins (MMP-7 and -13), and other variants (see Table 1) [17]. Together, the MMP substrate repertoire includes the extracellular matrix components, fibrillar collagens, elastin as well as matrix proteoglycan core proteins, and furthermore an expanding range of nonmatrix substrates [18, 19]. MMPs are synthesized in an inactive proform that is activated extracellularly by proteolytic cleavage under the regulation of several inflammatory mediators, including cytokines, chemokines, free radicals and steroids [20, 21]. Moreover certain MMPs are able to activate others; for example, MMP-12 was shown to activate MMP-2 and MMP-3, thereby leading to an exacerbation of proteolytic processes [22].

As proteolytic enzymes, MMPs have important roles in development and physiology. They are thus linked to physiological activities in the CNS, such as myelin formation, axonal growth, angiogenesis, and regeneration [23, 24]. In general, a deviant expression or overproduction of these MMPs leads to tissue destruction, and may contribute to brain pathologies such as Alzheimer's disease, ischemia, malignant glioma, and Parkinson's disease [25-29], when not counterbalanced by their physiological inhibitors, the tissue inhibitors of MMPs, TIMPs [18] (see Figure 1). Usually MMPs are under strict control at various levels: gene transcription, synthesis, secretion, activation, inhibition and glycosylation. Therefore, normal adult CNS contains low levels of most MMP members [30], in contrast to various neurological disorders of the CNS in which several MMPs are significantly upregulated [31].

The upregulated MMPs in the CNS have several potentially detrimental roles, including the promotion of neuroinflammation, disruption of the blood brain barrier (BBB) $[20,32]$, demyelination, and damage to axons and neurons (especially MMP-1 and MMP-2) [33]. MMPs also participate in the inflammatory cascade itself by actions on inflammatory mediators and their receptors [34, 35]. Thereby, several MMPs may act in concert in a so called MMP cascade [13]. Moreover, MMPs may contribute indirectly to the expansion of the inflammatory response and tissue damage by generating antigens through the breakdown of myelin or by conversion of inactive membrane bound TNF- $\alpha$ into the active myelinotoxic form [36]. Similar molecules (e.g., TNF receptors, L-selectin, TGF- $\beta$ and FAS ligand) may, due to the action of MMPs, undergo analogous processes [37]. The definite sources of the activated MMPs are still to be determined: invading $\mathrm{T}$ cells may release proinflammatory cytokines that activate glia cells, which are in control of the expression, secretion and balance between MMPs, as well as the secretion of their natural and specific inhibitors (TIMPS).

\section{Microglia in Inflammation}

The primary immune effector cells of the brain are microglia, which are activated in response to brain injury or inflammatory conditions. Most likely, they play a pivotal role during onset, maintenance, relapse and progression of an inflammatory state. In the course of activation, they do not only release neurotrophic factors (such as nerve growth factor and brainderived neurotrophic factor), but also neurotoxic factors (e.g., nitric oxide) and proinflammatory cytokines (TNF- $\alpha$ and IL-1) [38, 39]. Thus microglial activation is necessary for host defense, but this comes at the prize of additional "bystander damage" [40]. There is evidence that microglia play a detrimental role in various neurodegenerative diseases $[41,42]$. However, ample data demonstrate beneficial roles for microglia, for example, by stimulating myelin repair, removal of toxic proteins from the CNS, and the prevention of chronic neurodegeneration [43, 44]. Microglial activation can be caused by neuronal cell death leading to secretion of signaling molecules (including $\alpha$-synuclein, neuromelanin, and active forms of MMP-3) $[38,39,45,46]$. The expression of MMPs, produced in microglia at sites of inflammation upon activation (such as LPS and Con A $[47,48]$, could be shown in various studies $[1,49,50]$. Particularly the secreted MMP-2 and MMP-9 $[16,51]$ seem to be the key modulators (Figure 2).

\section{MMP-2 and MMP-9 in Inflammation}

MMP-2 and MMP-9 are structurally related and share the common feature of a zinc-binding domain. MMP-2 (gelatinase A a $72 \mathrm{kDa}$ type IV collagenase) and MMP-9 (gelatinase $\mathrm{B}$ a $92 \mathrm{kDa}$ type IV and type $\mathrm{V}$ collagenase) degrade collagens IV and $\mathrm{V}$ in their native forms [52]. Besides collagen, MMP-9 targets a variety of other substrates, for example, substance 


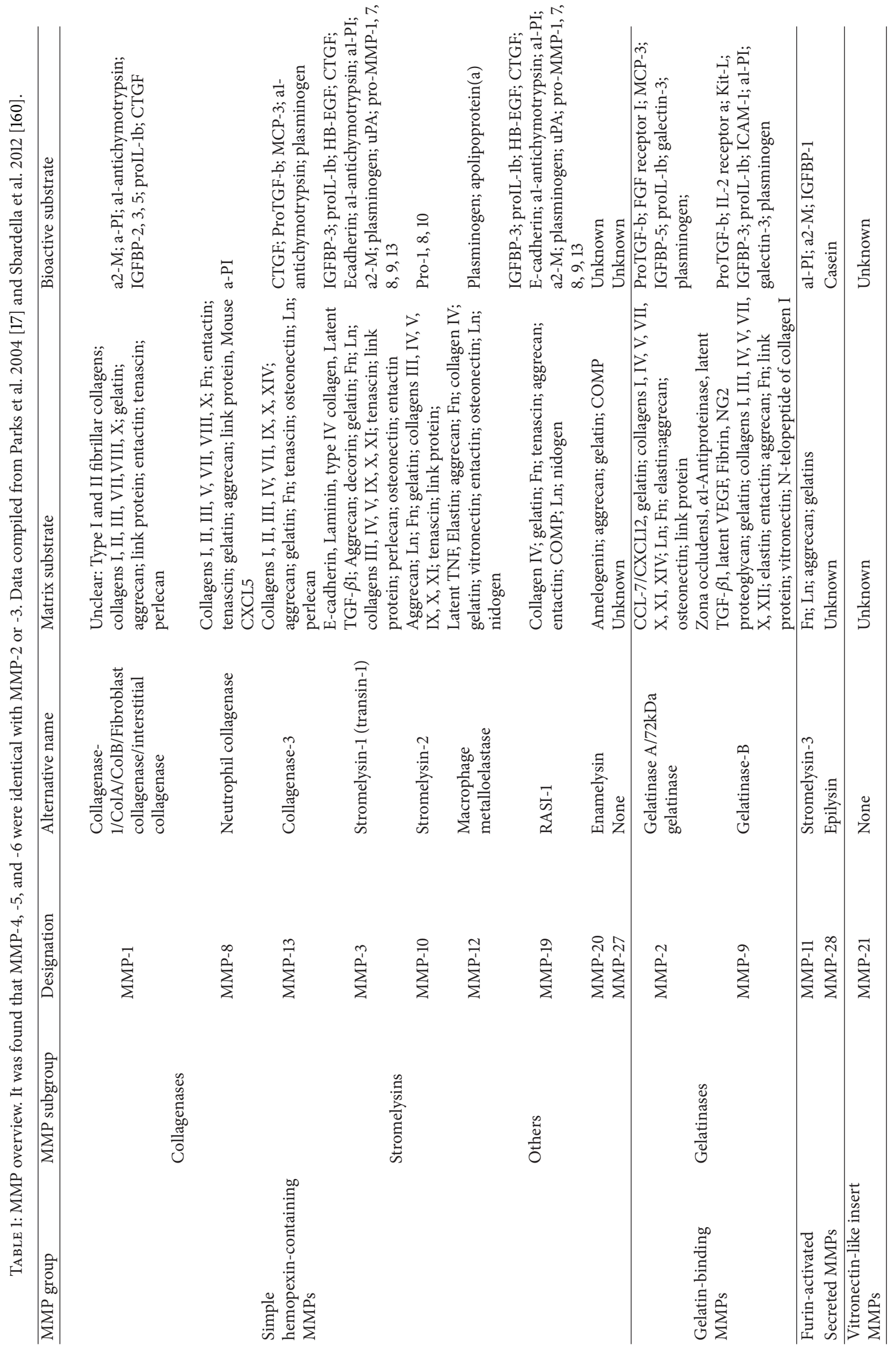




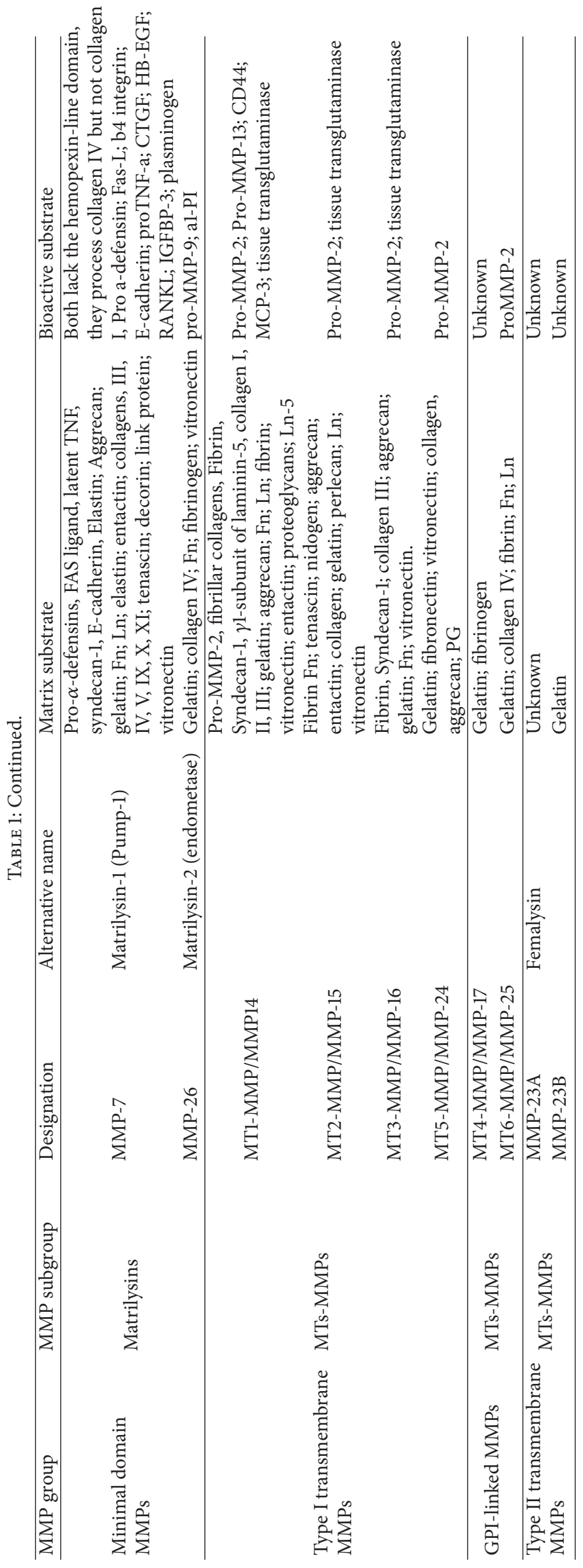




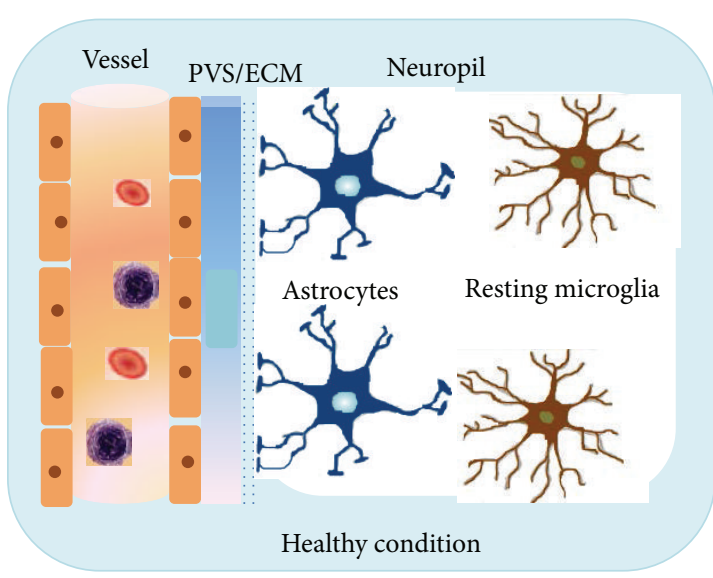

(a)

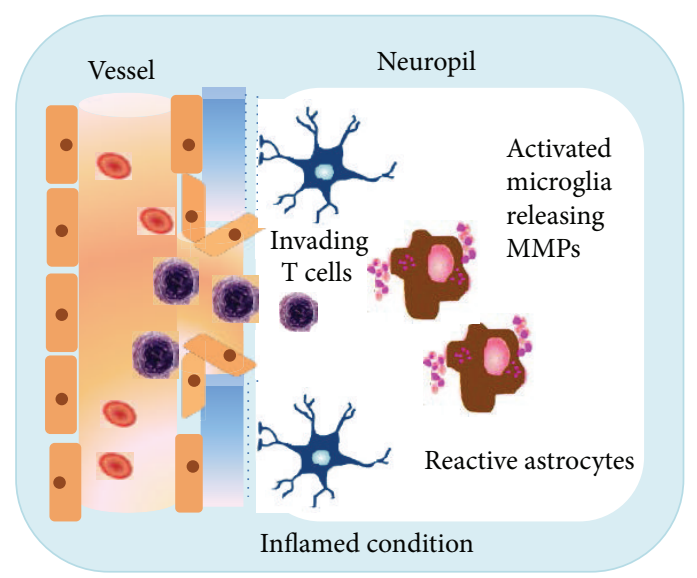

(b)

FIGURE 2: The blood brain barrier (BBB) in healthy and inflamed condition. (a) Vessel, endothelium, extracellular matrix (ECM), and glia limitans are intact. Microglia cells are in a resting state. (b) In the inflammed CNS breakdown of the BBB takes places. The glia limitans is opened, and astrocytic endfeet are drawn away. Reactive microglia secrete MMPs facilitating the opening of the BBB. Invading T cells migrate from the vessel via the perivascular space (PVS) into the neuropil.

$\mathrm{P}$ [53] and b-amyloid (1-40) [54], and MMP-2 cleaves bamyloid (1-40) and b-amyloid (1-42) [55]. MMP-9 can also degrade human myelin basic protein (MBP), thereby directly contributing to myelin damage [56-58].

MMP-9 was called a tuner and amplifier of immune functions [59], because of its assistance in peripheralization of leukocytes in response to chemokines [59] into sites of inflammation and by acting as switch and catalyst at the interplay between the innate and adaptive immune systems. MMP-9 has been implicated in opening the route for immune cells into the neuropil in various diseases, including not only MS but also strokes and brain injuries [1, 25, 31, 6065]. In fact, the infarct size can be lessened by reducing the MMP-9 activity with a monoclonal antibody [66] or through enzymatic inhibition respectively, gene knockout [65].

Although the cause of MS remains unknown, MMPs are implicated in the pathology of MS. Focal BBB leakage and extravasation of immune cells into the brain parenchyma are the earliest steps in the pathogenesis of MS as mentioned above [67, 68]. MMPs are effectors of BBB disruption [69]; extensive studies in MS and EAE demonstrated especially activity of MMP-2 [70] and MMP-9 [71, 72]. MMP-9 around blood vessels suggest that MMP-9 might be pathologically involved in the disruption of the parenchymal basement membranes [73], paving the way for infiltrating cells of the immune system [1]. Within the CNS immune cells orchestrate myelin and axonal destruction resulting in severe destruction of normal CNS constituents. The histopathological hallmark of MS is the plaque, a well-demarcated white matter lesion characterized by demyelination and axonal loss. Expression of MMP-1, -2, -3, -7, and -9 in monocytes/ macrophages, microglia, astrocytes, and lymphocytes around perivascular cuffs in MS lesions has been described [73-75]. We could also confirm by immunostaining that microglia are sources of MMP-2 and MMP-9 (see Figure 3).

The secreted MMP-9 can cause demyelination and axonal injury $[76,77]$. Axonal damage is considered to be a major cause of secondary progression (with irreversible neurological impairment) [78-80], which seems to be caused not only by $\mathrm{T}$ cells [81] but also by microglia/macrophages and their toxic products $[75,82,83]$. Cuzner et al. [84] could confirm enhanced MMP-9 expression in reactive microglia and astrocytes in autopsies from MS brains. Interestingly, intrathecal synthesis of MMP-9 appears to be specific for MS $[85,86]$. Around the time of onset of the symptoms in EAE, elevated levels of MMP-9 can be found. The administration of GM6001 (a MMP inhibitor) improved the clinical condition by blocking the BBB injury [87].

The view that MMP-9 is a promoter of neuroinflammation has been additionally supported by the finding that young (3-4 weeks) but not older (7-8 weeks) MMP-9 null mice were less susceptible to development of EAE than wild type controls [71]. In addition, MMP-2 null mice were reported to have an earlier onset and more severe disease compared to wild type controls. Apparently this was related to a compensatory increase of MMP-9 in the MMP-2 null mice [71]. Enzyme inhibitors of MMPs have been shown to ameliorate the clinical course and reduce inflammatory cell infiltration in EAE [87-89]. Treatment of PTxinjected CCL2-overexpressing mice with the synthetic broadspectrum inhibitor BB-94 (Batimastat) alleviated symptoms of neuroinflammation [90] and put blood-derived cells on hold in perivascular spaces. This was the first evidence that the second step of neuroinflammation, that is, passage of the glia limitans, but not the first, migration across the vascular wall, depends on MMPs.

The production of MMP-9 is negatively regulated by IL- 4 [91], IL-10 [92], and interferon- $\beta$ [93] whereas transforming growth factor- $\beta$ was found to enhance the production of MMP-9 in transformed lymphocytes [94]. Furthermore it was shown that cytokines, chemokines $[95,96]$, eicosanoides and peptidoglycan, lectins, double-stranded RNS and endotoxin $[31,59,65,97,98]$ are acting as soluble upregulators [99101]. Potent stimulators of MMP-9 and MMP-2 expression in 

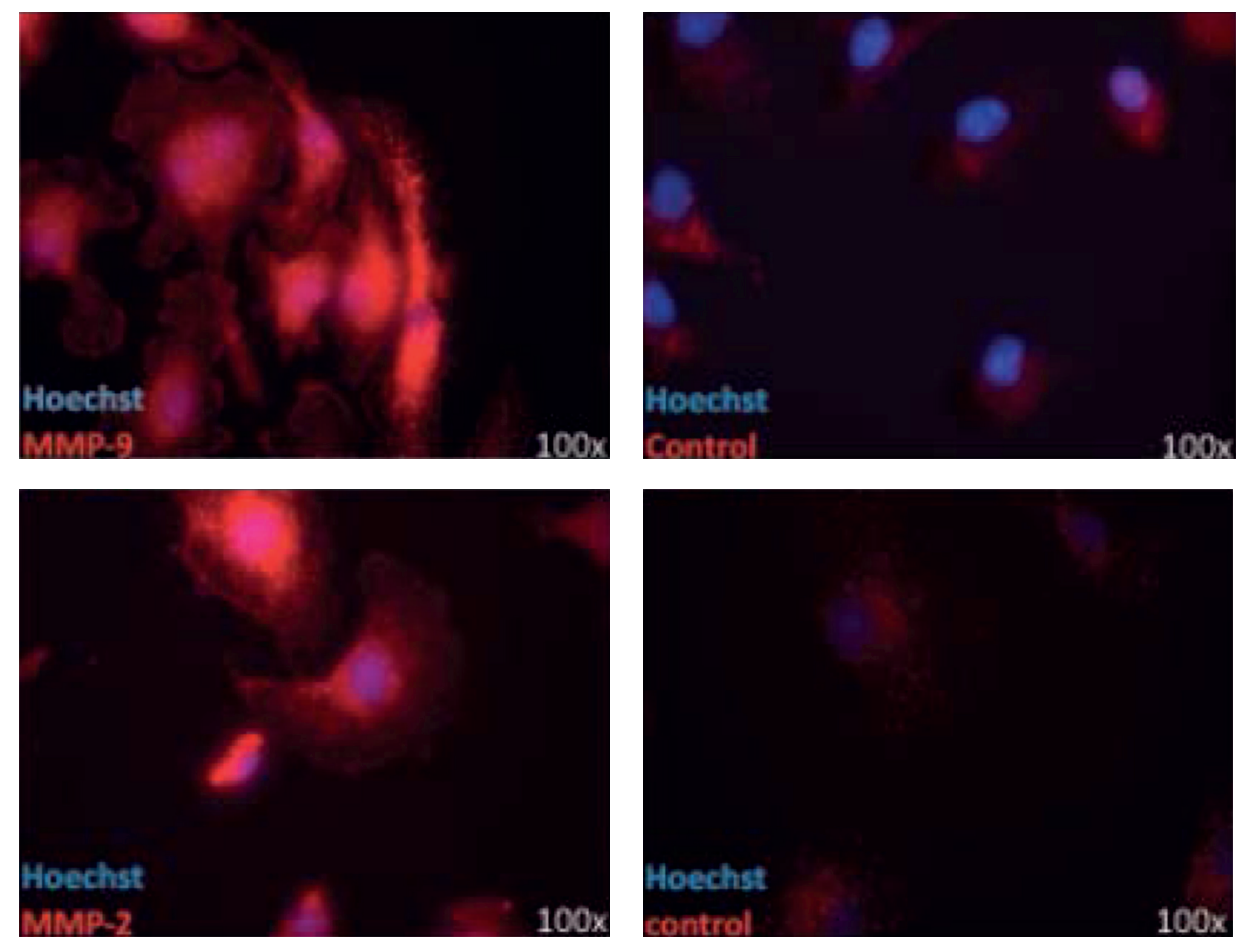

FIGURE 3: Immunohistochemistry of murine microglia, stained for MMP-2 and MMP-9. Microglia from CD1lc GFP mice, fixed with PFA, treated with TBS and NGS, anti-MMP-2 (1:125) and anti-MMP-9 (1:500); control: BSA and secondary antibodies.

cultured astrocytes and microglia are the proinflammatory cytokines interleukin 1 (IL-1), tumor necrosis factor-alpha (TNF- $\alpha$ ), and lipopolysaccharide (LPS) $[102,103]$.

Furthermore, interferon- $\beta$ (an immune-modulator that is commonly used in MS) inhibits the expression of MMPs in glial cells. Liuzzi et al. [104] demonstrated that LPS treated microglia secreted higher levels of MMP-9. As soon as the microglia cells were pre-/treated with different doses of IFN$\beta$ they found dose-dependent inhibition of MMP-9. IFN$\gamma$ or IFN- $\beta$ was also suggested to inhibit the expression of MMP-9 in human astroglioma and fibrosarcoma cell lines, as well as in primary astrocytes, supposable by the modulation of transcription factors that regulate the MMP9 transcription $[105,106]$. Still an indirect pathway cannot be excluded: IFN- $\beta$ could regulate the MMP expression either through the reduction of proinflammatory cytokines or by the inhibition of the activity of enzymes involved in MMP activation [107]. IFN- $\beta$ also reduces the production of MMP-9 by $\mathrm{T}$ cells and monocytes in vitro $[8,108,109]$ leading to diminished MMP-9 levels in serum of multiple sclerosis patients $[110,111]$. This was paralleled by the clinical recovery of the patients, presumably as a result of a significant reduction of $\mathrm{T}$ lymphocytes infiltrating in the brain. Besides interferon- $\beta$ also increases gene transcription of TIMP-1, thus attenuating MMP overactivity in MS. Intravenous gamma globulins (IVIG) used in severe cases of MS were shown to diminish the amount of secreted MMP-9 and its mRNA expression [112].

In addition to their detrimental roles MMPs might also have a beneficial effect in MS, as they also have important functions in (the developmental) plasticity of the nervous system [70, 113, 114]: MMP-9 mediates the oligodendrocytes process outgrowth [115]. Cultured oligodendrocytes secrete MMP-9, and cell-associated gelatinases are found at the site of their growing tips of their processes [116].

Notably MMP-9 is significantly upregulated in the acute period of spinal cord injury $[117,118]$ which might promote the maturation of oligodendrocytes and their formation of myelin [119]. MMP-9 [115, 116] and MMP-12 [120] are expressed by oligodendrocytes and seem to be essential for regulating the extension of their processes. Remyelination was impaired in MMP-9 and MMP-9/-12-null mice, correlating with fewer mature oligodendrocytes [121]. Taking that into account the MMP-9 secretion by microglia might allow a microenvironment in lesions for better remyelination and repair [31]. MMP-2 levels increase between 7 and 14 days after spinal cord injury, and MMP-2 null mice do not recover equally well as wild type controls do suggesting that the delayed expression is necessary for ECM remodeling and functional recovery [122].

MMP-1, MMP-3, and MMP-8 were also reported to play a role in $\mathrm{BBB}$ disruption followed by a leukocyte infiltration into the brain [123, 124]. Woo et al. [125] demonstrated that the mRNA expression of MMP-1, $-3,-8$, and -9 in primary cultured microglia cells was significantly increased by LPS and other immunostimulants. Furthermore, the inhibition of MMP-3 and MMP-9 could suppress inflammatory reactions in activated microglia (such as iNOS, proinflammatory cytokine expression, and upstream signaling molecules such as MAPKs, which would amplify the inflammatory cascade by initiating the MMP production in an autocrine or paracrine way). 


\section{Conclusion}

The data discussed beforehand reinforces the concept that leukocyte transmigration involves distinct molecular mechanisms. MMP-2 and MMP-9 are expressed by microglial cells which contribute to the formation of the glia limitans [126]. These cell types might be responsible for the opening of the glia limitans and the further progression of autoreactive immune cells into the neuropil. Besides the contribution of MMP-9 to BBB breakdown, it is also involved in the generation of autoimmune epitopes as well as the bioavailability of cytokines.

The treatment of neurological inflammation still remains a challenge today. Targeting MMPs in the CNS may serve as therapeutic option in autoimmune diseases. It is tempting to employ inhibitors of MMP activity to abrogate increased MMP expression (partially driven by microglial activation) within the inflamed CNS. However, MMPs also fulfill beneficial roles in the CNS, including mediation of tissue repair [31], synaptic plasticity [127], learning, and memory [128]. With respect to the multiple roles of MMPs, not only detrimental but also physiological, the need and the judicious application of specific inhibitors against individual MMPs should be highlighted. Due to their bifaced role, timing may also be crucial for therapeutic effects. There is the likelihood that nonspecific MMP inhibitors, although protecting against particular detrimental effects of some MMPs, could block useful actions of MMPs, thus slowing down disease recovery, too. It will be necessary to analyze further therapies aimed at decreasing MMP-2 and MMP-9 expression or activity.

\section{Microglia and Gliomas}

The most common brain tumors are malignant gliomas, infiltrating diffusely into normal brain parenchyma [129]. So far all current (multimodal) therapeutic approaches were ineffective, and life expectancy from the time of the diagnosis in glioblastoma multiforme is on average 14 months [130133].

In 1921 Rio-Hortega [134], was the first to describe the presence of microglia cells in brain tumors. Microglia contribute substantially (at least $1 / 3$ ) to the tumor mass of glioblastoma as they make up the largest population of tumor-infiltrating cells [135-138]. Microglia seem to possess a decisive tumor-supporting role by creating a microenvironment, which plays a critical role in tumor initiation and progression [139-144]. This special environment is also an immunosuppressive milieu, where, for example, IL-10 is released $[135,145,146]$. Microglia/macrophages play also an influential role in glioma invasion: there is a positive correlation in their density in gliomas with the invasiveness and grade of gliomas $[139,144]$. The antitumor properties, namely glioma-cytotoxic effects of microglia, could only be shown in vitro so far $[147,148]$. Favoring gliomas' growth could be due to a suppression and/or control of microglial cells by glioma cells and glioma-derived molecules (e.g., their loss of phagocytic function [149]. It was also suggested that, under the influence of glioma cells, microglia develop a different, noninflammatory phenotype suppressing their defense properties $[139,144,150]$. Instead of releasing proinflammatory cytokines, microglia upregulate enzymes that facilitate tumor invasion and proliferation. A key mechanism in the expansion and invasion of gliomas is the degradation of extracellular matrix by membrane-bound or secreted proteases such as MMPs [151], especially matrixmetalloproteinase-2 [152] and MMP-9 [151].

\section{MMPs and Glioma Cells}

Due to their ECM-degrading ability and confirmed upregulation in almost all cancer entities, MMP-2 has been linked to invasiveness and dissemination [153-155]. Because serum concentration of MMP-2 was significantly elevated in tumor patients, MMP-2 was suggested as a diagnostic and prognostic marker $[156,157]$. On the other hand elevated MMP-9 levels in the serum seem to be even more relevant values, because in healthy individuals under physiological conditions MMP-9 is hardly detectable [158]. Abnormal MMP-9 concentrations in patients serum were also shown for brain cancers [159], and notably there is a positive correlation with poor prognosis [160].

So far, there is no evidence that links MMP-2 to a special phase of tumor development (in contrast to MMP-9): besides creating a microenvironment in the early phase favoring cancer growth (activation of growth factors), the transition into an undifferentiated phenotype permitting migration and invasiveness is also related to MMP-2 activity, for example, the proteolytic detachment of adhesion molecules like integrins or cadherins or cytoskeleton changes [161, 162]. MMP2 acts in multiple ways on tumor cells by modulation of their metabolism, their receptor turnover [163], and their resistance to apoptosis [164]. In fact, anti-MMP-2 siRNAtreated glioma cells underwent apoptosis [165] and MMP-2 inhibition autophagy-associated cell death [166].

The expression of the MMP-2 gene in human glioma tissues was found to be upregulated in comparison to normal brain tissue, and dramatically increased in glioblastomas [167-169]. MMP-9 expression could be correlated with high malignancy and progression of gliomas [170, 171]. Various studies show that glioma and microglia cells both produce MMP-2 in vitro [144, 168] and in situ [172]. However, MMP-2 is released as an inactive profrom by glioma cells (especially at the invasive tumor zone), and glioma cells themselves are unable to activate pro-MMP-2. Since the extracellular activator MT1-MMP is highly upregulated in glioma infiltrating microglia [138, 151, 172, 173], glioma cells engage microglial cells to promote their spread and survival [174]. This concept of microglial "abuse" has been impressively demonstrated by the group of Kettenmann [138].

\section{Pathways of MMP Induction and Suppression in Gliomas}

Another key player of glioma motility and invasion seems to be FasL, which is expressed in tumor cells. It not only induces apoptosis in $\mathrm{T}$ cells thereby leading to local immunosuppression, but blockade of Fas signaling resulted in impaired 


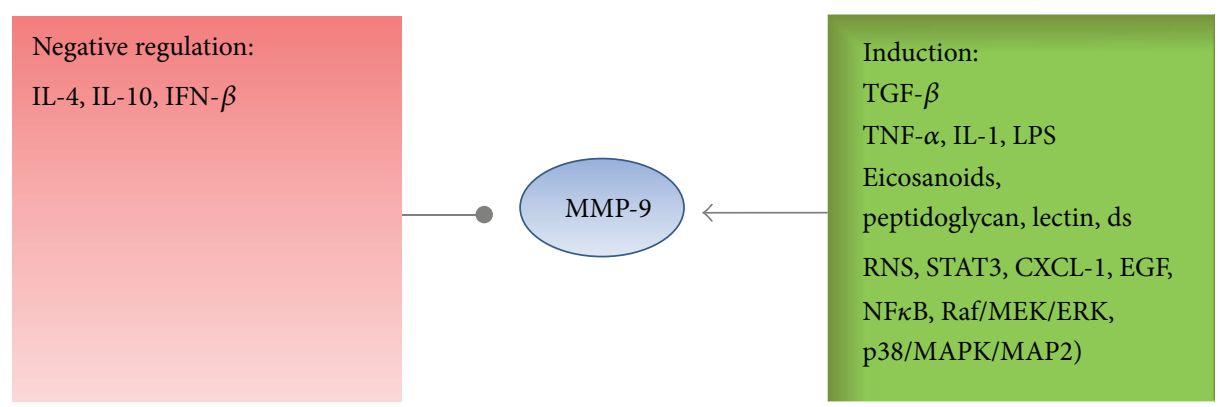

FIGURE 4: Regulation and induction of MMP-9: a variety of molecules are involved.

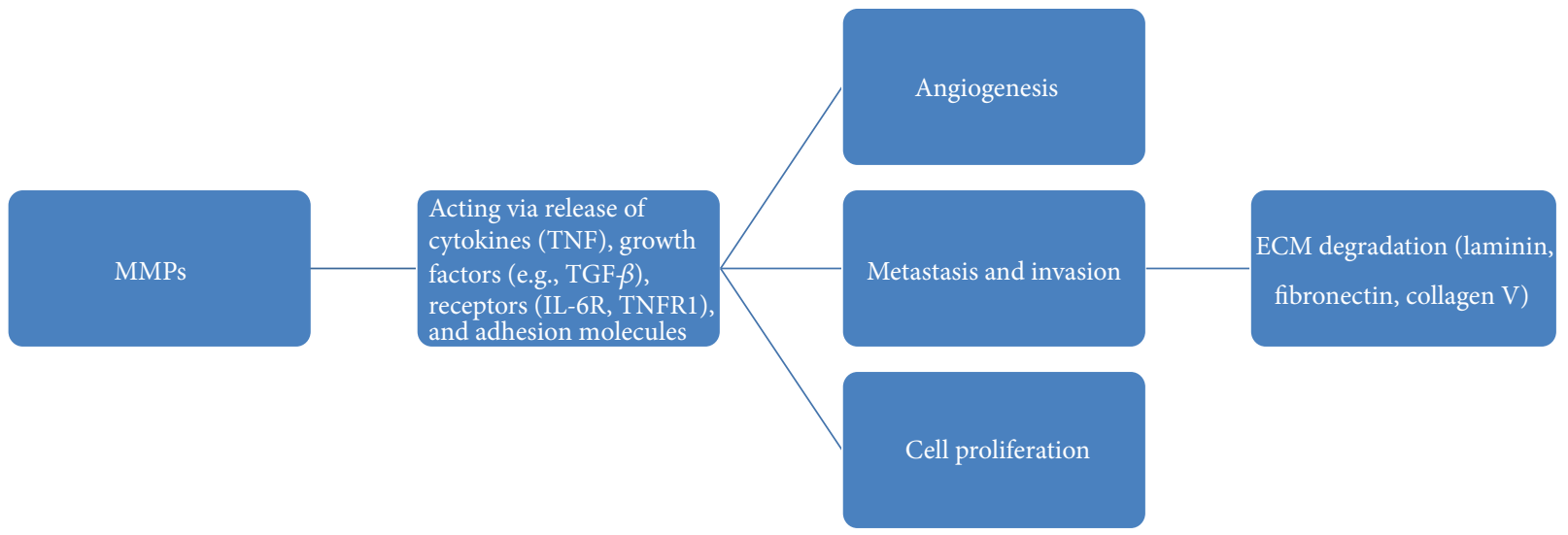

FIGURE 5: MMP in gliomas: the various roles of MMPs in promoting the growth of cancer cells.

MMP-2 activity with a subsequent reduction of glioma invasiveness and motility [175]. The expression of MMPs is also facilitated by glioma-derived TGF- $\beta$ which suppresses the expression of TIMPs and also has an immunosuppressive role [176-178]. The inactive precursor of TGF- $\beta$ can be processed by MMP-2 $[179,180]$, and TGF- $\beta$ induces gene transcprition of MMP-2, thus generating a vicious circle leading to further tumor growth [181, 182] (Figure 4).

Another player in glioma growth, gliomagenesis, and progression is the activation of STAT3 [183]. This signal transducer and activator of transcription protein 3 is constitutively activated in glioblastoma cell lines [184-187] and increases MMP-9 expression and activation in human astrocytoma cell lines [188, 189]. The expression of MMP-2, -9, and -14 in microglia/macrophages was also shown to be enhanced by glioma-derived CX3CL1 (Chemokine (C-X3-C Motif) Ligand) and is significantly associated with the recruitment of microglia into the tumor [190]. Another role in the production of MMP-9 in glioma cells is played by protein kinase C (PKC) [191] and IL-6 is a confirmed growth factor for glioma stem cells, too [192]. The tumor-promoting role of IL6 may be exerted via MMP-2, whose production is increased by IL-6 [193]. Glioma-induced MMP-2 activity in microglia could be significantly decreased by the A1AR (an adenosine receptor subtype, found on microglia and neurons) [194], which might explain the fact that adenosine treatment leads to decreased extracellular protease activity and thereby exerts its inhibitory effects on glioma invasion. Early studies in MS patients could also show that A1AR activation in microglia interfered with the MMPs production [195].

Although the substrate specifity of MMP-2 and MMP-9 overlaps, MMP-9 (in contrast to MMP-2) is highly inducible mostly by integrins, growth factors, and cytokines [13, 196] leading to a defined chronologically and spatially distribution. The expression of MMP-9 is further triggered by autocrine or paracrine mechanisms (IL- $1 \beta$, TNF- $\alpha$, and TGF$\beta$ ), cell binding (to fibronectin or vitronectin), EGF release or distinct molecular pathways (transcription factors NF$\kappa \mathrm{B}$, Raf/MEK/ERK cascade, or the p38 MAPK/MAPK2signaling) [180, 196-200] (Figure 5).

In sum, ample data describe the communication between tumor cells and microglia. Microglia and their expression of MMPs could be a crucial target for future therapeutic options in gliomas, due to their profound involvement in tumor progression.

\section{References}

[1] G. A. Rosenberg, "Matrix metalloproteinases in neuroinflammation," GLIA, vol. 39, no. 3, pp. 279-291, 2002.

[2] R. Tanaka, Y. Iwasaki, and H. Koprowski, "Ultrastructural studies of perivascular cuffing cells in multiple sclerosis brain," American Journal of Pathology, vol. 81, no. 3, pp. 467-478, 1975.

[3] I. Bechmann, I. Galea, and V. H. Perry, "What is the blood-brain barrier (not)?” Trends in Immunology, vol. 28, no. 1, pp. 5-11, 2007. 
[4] A. Uccelli, F. Aloisi, and V. Pistoia, "Unveiling the enigma of the CNS as a B-cell fostering environment," Trends in Immunology, vol. 26, no. 5, pp. 254-259, 2005.

[5] W. F. Hickey, "Basic principles of immunological surveillance of the normal central nervous system," GLIA, vol. 36, no. 2, pp. 118-124, 2001.

[6] E. J. Goetzl, M. J. Banda, and D. Leppert, "Matrix metalloproteinases in immunity," Journal of Immunology, vol. 156, no. 1, pp. $1-4,1996$.

[7] J. A. Madri and D. Graesser, "Cell migration in the immune system: the evolving inter-related roles of adhesion molecules and proteinases," Developmental Immunology, vol. 7, no. 2-4, pp. 103-116, 2000.

[8] D. Leppert, E. Waubant, R. Galardy, N. W. Bunnett, and S. L. Hauser, "T cell gelatinases madiate basement membrane transmigration in vitro," Journal of Immunology, vol. 154, no. 9, pp. 4379-4389, 1995.

[9] M. Xia, S. P. Sreedharan, P. Dazin, C. H. Damsky, and E. J. Goetzl, "Integrin-dependent role of human T cell matrix metalloproteinase activity in chemotaxis through a model basement membrane," Journal of Cellular Biochemistry, vol. 61, no. 3, pp. 452-458, 1996.

[10] G. Graesser, "Integrins, proteinases, and EAE: Explaining a complex web of interactions," Laboratory Investigation, vol. 78, no. 12 , p. $1445,1998$.

[11] G. W. Laurie, C. P. Leblond, and G. R. Martin, "Localization of type IV collagen, laminin, heparan sulfate proteoglycan, and fibronectin to the basal lamina of basement membranes," Journal of Cell Biology, vol. 95, no. 1, pp. 340-344, 1982.

[12] M. Sixt, B. Engelhardt, F. Pausch, R. Hallmann, O. Wendler, and L. M. Sorokin, "Endothelial cell laminin isoforms, laminins 8 and 10, play decisive roles in $\mathrm{T}$ cell recruitment across the bloodbrain barrier in experimental autoimmune encephalomyelitis," Journal of Cell Biology, vol. 153, no. 5, pp. 933-945, 2001.

[13] P. E. van den Steen, B. Dubois, I. Nelissen, P. M. Rudd, R. A. Dwek, and G. Opdenakker, "Biochemistry and molecular biology of gelatinase B or matrix metalloproteinase-9 (MMP9)," Critical Reviews in Biochemistry and Molecular Biology, vol. 37, no. 6, pp. 375-536, 2002.

[14] M. Tian, C. Jacobson, S. H. Gee, K. P. Campbell, S. Carbonetto, and M. Jucker, "Dystroglycan in the cerebellum is a laminin alpha 2-chain binding protein at the glial-vascular interface and is expressed in Purkinje cells," European Journal of Neuroscience, vol. 8, no. 12, pp. 2739-2747, 1996.

[15] M. L. Zaccaria, F. Di Tommaso, A. Brancaccio, P. Paggi, and T. C. Petrucci, "Dystroglycan distribution in adult mouse brain: a light and electron microscopy study," Neuroscience, vol. 104, no. 2, pp. 311-324, 2001.

[16] S. Agrawal, P. Anderson, M. Durbeej et al., "Dystroglycan is selectively cleaved at the parenchymal basement membrane at sites of leukocyte extravasation in experimental autoimmune encephalomyelitis," Journal of Experimental Medicine, vol. 203, no. 4, pp. 1007-1016, 2006.

[17] W. C. Parks, C. L. Wilson, and Y. S. López-Boado, "Matrix metalloproteinases as modulators of inflammation and innate immunity," Nature Reviews Immunology, vol. 4, no. 8, pp. 617629, 2004.

[18] R. Visse and H. Nagase, "Matrix metalloproteinases and tissue inhibitors of metalloproteinases: structure, function, and biochemistry," Circulation Research, vol. 92, no. 8, pp. 827-839, 2003.
[19] J. F. Woessner Jr., "Matrix metalloproteinases and their inhibitors in connective tissue remodeling," FASEB Journal, vol. 5, no. 8, pp. 2145-2154, 1991.

[20] M. D. Sternlicht and Z. Werb, "How matrix metalloproteinases regulate cell behavior," Annual Review of Cell and Developmental Biology, vol. 17, pp. 463-516, 2001.

[21] C. M. Alexander and Z. Werb, "Proteinases and extracellular matrix remodeling," Current Opinion in Cell Biology, vol. 1, no. 5, pp. 974-982, 1989.

[22] S. I. Matsumoto, T. Kobayashi, M. Katoh et al., "Expression and localization of matrix metalloproteinase-12 in the aorta of cholesterol-fed rabbits: relationship to lesion development," American Journal of Pathology, vol. 153, no. 1, pp. 109-119, 1998.

[23] V. W. Yong, C. Power, P. Forsyth, and D. R. Edwards, "Metalloproteinases in biology and pathology of the nervous system," Nature Reviews Neuroscience, vol. 2, no. 7, pp. 502-511, 2001.

[24] S. M. Agrawal, L. Lau, and V. W. Yong, "MMPs in the central nervous system: where the good guys go bad," Seminars in Cell and Developmental Biology, vol. 19, no. 1, pp. 42-51, 2008.

[25] G. A. Rosenberg, J. E. Dencoff, P. G. McGuire, L. A. Liotta, and W. G. Stetler-Stevenson, "Injury-induced 92-kilodalton gelatinase and urokinase expression in rat brain," Laboratory Investigation, vol. 71, no. 3, pp. 417-422, 1994.

[26] V. W. Yong, C. A. Krekoski, P. A. Forsyth, R. Bell, and D. R. Edwards, "Matrix metalloproteinases and diseases of the CNS," Trends in Neurosciences, vol. 21, no. 2, pp. 75-80, 1998.

[27] N. Ramos-DeSimone, E. Hahn-Dantona, J. Sipley, H. Nagase, D. L. French, and J. P. Quigley, "Activation of matrix metalloproteinase-9 (MMP-9) via a converging plasmin/stromelysin1 cascade enhances tumor cell invasion," Journal of Biological Chemistry, vol. 274, no. 19, pp. 13066-13076, 1999.

[28] S. Lorenzl, N. Calingasan, L. Yang et al., "Matrix metalloproteinase-9 is elevated in 1-methyl-4-phenyl-1,2,3,6-tetrahydropyridine-induced parkinsonism in mice," NeuroMolecular Medicine, vol. 5, no. 2, pp. 119-131, 2004.

[29] K. J. Yin, J. R. Cirrito, P. Yan et al., "Matrix metalloproteinases expressed by astrocytes mediate extracellular amyloid- $\beta$ peptide catabolism," Journal of Neuroscience, vol. 26, no. 43, pp. 10939-10948, 2006.

[30] A. Weaver, A. Goncalves da Silva, R. K. Nuttall et al., "An elevated matrix metalloproteinase (MMP) in an animal model of multiple sclerosis is protective by affecting Th1/Th2 polarization," The FASEB Journal, vol. 19, no. 12, pp. 1668-1670, 2005.

[31] V. W. Yong, "Metalloproteinases: mediators of pathology and regeneration in the CNS," Nature Reviews Neuroscience, vol. 6, no. 12, pp. 931-944, 2005.

[32] J. F. Woessner Jr., "Quantification of matrix metalloproteinases in tissue samples," Methods in Enzymology, vol. 248, pp. 510-528, 1995.

[33] C. M. P. Vos, S. Gartner, R. M. Ransohoff et al., "Matrix metalloprotease-9 release from monocytes increases as a function of differentiation: implications for neuroinflammation and neurodegeneration," Journal of Neuroimmunology, vol. 109, no. 2, pp. 221-227, 2000.

[34] J. Hu, P. E. van den Steen, Q. X. A. Sang, and G. Opdenakker, "Matrix metalloproteinase inhibitors as therapy for inflammatory and vascular diseases," Nature Reviews Drug Discovery, vol. 6, no. 6, pp. 480-498, 2007.

[35] A. Page-McCaw, A. J. Ewald, and Z. Werb, "Matrix metalloproteinases and the regulation of tissue remodelling," Nature Reviews Molecular Cell Biology, vol. 8, no. 3, pp. 221-233, 2007. 
[36] A. J. H. Gearing, P. Beckett, M. Christodoulou et al., "Processing of tumour necrosis factor- $\alpha$ precursor by metalloproteinases," Nature, vol. 370, no. 6490, pp. 555-557, 1994.

[37] S. Chandler, K. M. Miller, J. M. Clements et al., "Matrix metalloproteinases, tumor necrosis factor and multiple sclerosis: an overview," Journal of Neuroimmunology, vol. 72, no. 2, pp. 155161, 1997.

[38] M. L. Block, L. Zecca, and J. S. Hong, "Microglia-mediated neurotoxicity: uncovering the molecular mechanisms," Nature Reviews Neuroscience, vol. 8, no. 1, pp. 57-69, 2007.

[39] S. U. Kim and J. de Vellis, "Microglia in health and disease," Journal of Neuroscience Research, vol. 81, no. 3, pp. 302-313, 2005.

[40] W. J. Streit, J. R. Conde, S. E. Fendrick, B. E. Flanary, and C. L. Mariani, "Role of microglia in the central nervous system's immune response," Neurological Research, vol. 27, no. 7, pp. 685691, 2005.

[41] P. L. McGeer, S. Itagaki, B. E. Boyes, and E. G. McGeer, "Reactive microglia are positive for HLA-DR in the substantia nigra of Parkinson's and Alzheimer's disease brains," Neurology, vol. 38, no. 8, pp. 1285-1291, 1988.

[42] H. M. Gao, B. Liu, and J. S. Hong, "Critical role for microglial NADPH oxidase in rotenone-induced degeneration of dopaminergic neurons," Journal of Neuroscience, vol. 23, no. 15, pp. 6181-6187, 2003.

[43] I. Glezer, A. R. Simard, and S. Rivest, "Neuroprotective role of the innate immune system by microglia," Neuroscience, vol. 147, no. 4, pp. 867-883, 2007.

[44] A. R. Simard and S. Rivest, "Neuroprotective effects of resident microglia following acute brain injury," Journal of Comparative Neurology, vol. 504, no. 6, pp. 716-729, 2007.

[45] Y. S. Kim and T. H. Joh, "Microglia, major player in the brain inflammation: their roles in the pathogenesis of Parkinson's disease," Experimental and Molecular Medicine, vol. 38, no. 4, pp. 333-347, 2006.

[46] Y. S. Kim, D. H. Choi, M. L. Block et al., "A pivotal role of matrix metalloproteinase-3 activity in dopaminergic neuronal degeneration via microglial activation," The FASEB Journal, vol. 21, no. 1, pp. 179-187, 2007.

[47] L. M. Wahl and L. L. Lampel, "Regulation of human peripheral blood monocyte collagenase by prostaglandins and antiinflammatory drugs," Cellular Immunology, vol. 105, no. 2, pp. 411-422, 1987.

[48] Y. Lu and L. M. Wahl, "Oxidative stress augments the production of matrix metalloproteinase-1, cyclooxygenase-2, and prostaglandin E2 through enhancement of NF- $\kappa \mathrm{B}$ activity in lipopolysaccharide-activated human primary monocytes," Journal of Immunology, vol. 175, no. 8, pp. 5423-5429, 2005.

[49] G. M. Liuzzi, T. Latronico, A. Fasano, G. Carlone, and P. Riccio, "Interferon-beta inhibits the expression of metallo proteinases in rat glial cell cultures: implications for multiple sclerosis pathogenesis and treatment," Multiple Sclerosis, vol. 10, no. 3, pp. 290-297, 2004.

[50] R. K. Nuttall, C. Silva, W. Hader et al., "Metalloproteinases are enriched in microglia compared with leukocytes and they regulate cytokine levels in activated microglia," GLIA, vol. 55, no. 5, pp. 516-526, 2007.

[51] N. L. Webster and S. M. Crowe, "Matrix metalloproteinases, their production by monocytes and macrophages and their potential role in HIV-related diseases," Journal of Leukocyte Biology, vol. 80, no. 5, pp. 1052-1066, 2006.
[52] P. Mignatti and D. B. Rifkin, "Biology and biochemistry of proteinases in tumor invasion," Physiological Reviews, vol. 73, no. 1, pp. 161-195, 1993.

[53] J. R. Backstrom and Z. A. Tokes, "The $84-\mathrm{kDa}$ form of human matrix metalloproteinase-9 degrades substance P and gelatin," Journal of Neurochemistry, vol. 64, no. 3, pp. 1312-1318, 1995.

[54] J. R. Backstrom, G. P. Lim, M. J. Cullen, and Z. A. Tökés, "Matrix metalloproteinase-9 (MMP-9) is synthesized in neurons of the human hippocampus and is capable of degrading the amyloid- $\beta$ peptide (1-40)," Journal of Neuroscience, vol. 16, no. 24, pp. 79107919, 1996.

[55] A. E. Roher, T. C. Kasunic, A. S. Woods, R. J. Cotter, M. J. Ball, and R. Fridman, "Proteolysis of A $\beta$ peptide from Alzheimer disease brain by gelatinase A," Biochemical and Biophysical Research Communications, vol. 205, no. 3, pp. 1755-1761, 1994.

[56] P. Proost, J. Van Damme, and G. Opdenakker, "Leukocyte gelatinase B cleavage releases encephalitogens from human myelin basic protein," Biochemical and Biophysical Research Communications, vol. 192, no. 3, pp. 1175-1181, 1993.

[57] K. Gijbels, P. Proost, S. Masure, H. Carton, A. Billiau, and G. Opdenakker, "Gelatinase B is present in the cerebrospinal fluid during experimental autoimmune encephalomyelitis and cleaves myelin basic protein," Journal of Neuroscience Research, vol. 36, no. 4, pp. 432-440, 1993.

[58] S. Chandler, R. Coates, A. Gearing, J. Lury, G. Wells, and E. Bone, "Matrix metalloproteinases degrade myelin basic protein," Neuroscience Letters, vol. 201, no. 3, pp. 223-226, 1995.

[59] G. Opdenakker, P. E. van den Steen, and J. van Damme, "Gelatinase B: a tuner and amplifier of immune functions," Trends in Immunology, vol. 22, no. 10, pp. 571-579, 2001.

[60] A. Lukes, S. Mun-Bryce, M. Lukes, and G. A. Rosenberg, "Extracellular matrix degradation by metalloproteinases and central nervous system diseases," Molecular Neurobiology, vol. 19, no. 3, pp. 267-284, 1999.

[61] G. A. Rosenberg, J. E. Dencoff, N. Correa Jr., M. Reiners, and C. C. Ford, "Effect of steroids on CSF matrix metalloproteinases in multiple sclerosis: relation to blood-brain barrier injury," Neurology, vol. 46, no. 6, pp. 1626-1632, 1996.

[62] G. A. Rosenberg, E. Y. Estrada, and J. E. Dencoff, "Matrix metalloproteinases and TIMPs are associated with blood-brain barrier opening after reperfusion in rat brain," Stroke, vol. 29, no. 10 , pp. 2189-2195, 1998.

[63] D. C. Anthony, K. M. Miller, S. Fearn et al., "Matrix metalloproteinase expression in an experimentally-induced DTH model of multiple sclerosis in the rat CNS," Journal of Neuroimmunology, vol. 87, no. 1-2, pp. 62-72, 1998.

[64] S. Mun-Bryce and G. A. Rosenberg, "Gelatinase B modulates selective opening of the blood-brain barrier during inflammation," American Journal of Physiology, vol. 274, no. 5, pp. R1203R1211, 1998.

[65] M. Asahi, K. Asahi, J. C. Jung, G. J. del Zoppo, M. E. Fini, and E. H. Lo, "Role for matrix metalloproteinase 9 after focal cerebral ischemia: effects of gene knockout and enzyme inhibition with BB-4," Journal of Cerebral Blood Flow \& Metabolism, vol. 20, no. 12, pp. 1681-199, 2000.

[66] A. M. Romanic, R. F. White, A. J. Arleth, E. H. Ohlstein, and F. C. Barone, "Matrix metalloproteinase expression increases after cerebral focal ischemia in rats: inhibition of matrix metalloproteinase-9 reduces infarct size," Stroke, vol. 29, no. 5, pp. 1020-1030, 1998.

[67] A. G. Kermode, A. J. Thompson, P. Tofts et al., "Breakdown of the blood-brain barrier precedes symptoms and other MRI 
signs of new lesions in multiple sclerosis. Pathogenic and clinical implications," Brain, vol. 113, part 5, pp. 1477-1489, 1990.

[68] E. E. Kwon and J. W. Prineas, "Blood-brain barrier abnormalities in longstanding multiple sclerosis lesions. An immunohistochemical study," Journal of Neuropathology and Experimental Neurology, vol. 53, no. 6, pp. 625-636, 1994.

[69] G. A. Rosenberg, "Matrix metalloproteinases in brain injury," Journal of Neurotrauma, vol. 12, no. 5, pp. 833-842, 1995.

[70] A. M. Romanic and J. A. Madri, "Extracellular matrix-degrading proteinases in the nervous system," Brain Pathology, vol. 4, no. 2, pp. 145-156, 1994.

[71] B. Dubois, S. Masure, U. Hurtenbach et al., "Resistance of young gelatinase B-deficient mice to experimental autoimmune encephalomyelitis and necrotizing tail lesions," Journal of Clinical Investigation, vol. 104, no. 11, pp. 1507-1515, 1999.

[72] B. C. Kieseier, R. Kiefer, J. M. Clements et al., "Matrix metalloproteinase- 9 and -7 are regulated in experimental autoimmune encephalomyelitis," Brain, vol. 121, part 1, pp. 159-166, 1998.

[73] R. L. Lindberg, C. J. de Groot, L. Montagne et al., "The expression profile of matrix metalloproteinases (MMPs) and their inhibitors (TIMPs) in lesions and normal appearing white matter of multiple sclerosis," Brain, vol. 124, no. 9, pp. 1743-1753, 2001.

[74] A. Maeda and R. A. Sobel, "Matrix metalloproteinases in the normal human central nervous system, microglial nodules, and multiple sclerosis lesions," Journal of Neuropathology and Experimental Neurology, vol. 55, no. 3, pp. 300-309, 1996.

[75] J. A. Cossins, J. M. Clements, J. Ford et al., "Enhanced expression of MMP-7 and MMP-9 in demyelinating multiple sclerosis lesions," Acta Neuropathologica, vol. 94, no. 6, pp. 590-598, 1997.

[76] M. Diaz-Sanchez, K. Williams, G. C. DeLuca, and M. M. Esiri, "Protein co-expression with axonal injury in multiple sclerosis plaques," Acta Neuropathologica, vol. 111, no. 4, pp. 289-299, 2006.

[77] T. A. Newman, S. T. Woolley, P. M. Hughes, N. R. Sibson, D. C. Anthony, and V. H. Perry, "T-cell- and macrophagemediated axon damage in the absence of a CNS-specific immune response: involvement of metalloproteinases," Brain, vol. 124, no. 11, pp. 2203-2214, 2001.

[78] A. Bitsch, J. Schuchardt, S. Bunkowski, T. Kuhlmann, and W. Brück, "Acute axonal injury in multiple sclerosis. Correlation with demyelination and inflammation," Brain, vol. 123, part 6, pp. 1174-1183, 2000.

[79] G. C. DeLuca, G. C. Ebers, and M. M. Esiri, "Axonal loss in multiple sclerosis: a pathological survey of the corticospinal and sensory tracts," Brain, vol. 127, no. 5, pp. 1009-1018, 2004.

[80] B. D. Trapp, J. Peterson, R. M. Ransohoff, R. Rudick, S. Mörk, and L. Bö, "Axonal transection in the lesions of multiple sclerosis," New England Journal of Medicine, vol. 338, no. 5, pp. 278-285, 1998.

[81] T. Kuhlmann, G. Lingfeld, A. Bitsch, J. Schuchardt, and W. Brück, "Acute axonal damage in multiple sclerosis is most extensive in early disease stages and decreases over time," Brain, vol. 125, no. 10, pp. 2202-2212, 2002.

[82] A. Bitsch, C. Da Costa, S. Bunkowski, F. Weber, P. Rieckmann, and W. Brück, "Identification of macrophage populations expressing tumor necrosis factor- $\alpha$ mRNA in acute multiple sclerosis," Acta Neuropathologica, vol. 95, no. 4, pp. 373-377, 1998.

[83] P. D. Koeberle and A. K. Ball, "Nitric oxide synthase inhibition delays axonal degeneration and promotes the survival of axotomized retinal ganglion cells," Experimental Neurology, vol. 158, no. 2, pp. 366-381, 1999.

[84] M. L. Cuzner, D. Gveric, C. Strand et al., "The expression of tissue-type plasminogen activator, matrix metalloproteases and endogenous inhibitors in the central nervous system in multiple sclerosis: comparison of stages in lesion evolution," Journal of Neuropathology and Experimental Neurology, vol. 55, no. 12, pp. 1194-1204, 1996.

[85] G. M. Liuzzi, M. Trojano, M. Fanelli et al., "Intrathecal synthesis of matrix metalloproteinase-9 in patients with multiple sclerosis: implication for pathogenesis," Multiple Sclerosis, vol. 8, no. 3, pp. 222-228, 2002.

[86] D. Leppert, J. Ford, G. Stabler et al., "Matrix metalloproteinase-9 (gelatinase B) is selectively elevated in CSF during relapses and stable phases of multiple sclerosis," Brain, vol. 121, part 12, pp. 2327-2334, 1998.

[87] K. Gijbels, R. E. Galardy, and L. Steinman, "Reversal of experimental autoimmune encephalomyelitis with a hydroxamate inhibitor of matrix metalloproteases," Journal of Clinical Investigation, vol. 94, no. 6, pp. 2177-2182, 1994.

[88] A. K. Hewson, T. Smith, J. P. Leonard, and M. L. Cuzner, "Suppression of experimental allergic encephalomyelitis in the Lewis rat by the matrix metalloproteinase inhibitor Ro31-9790," Inflammation Research, vol. 44, no. 8, pp. 345-349, 1995.

[89] J. M. Clements, J. A. Cossins, G. M. Wells et al., "Matrix metalloproteinase expression during experimental autoimmune encephalomyelitis and effects of a combined matrix metalloproteinase and tumour necrosis factor-a inhibitor," Journal of Neuroimmunology, vol. 74, no. 1, pp. 85-94, 1997.

[90] H. Toft-Hansen, R. Buist, X. J. Sun, A. Schellenberg, J. Peeling, and T. Owens, "Metalloproteinases control brain inflammation induced by pertussis toxin in mice overexpressing the chemokine CCL2 in the central nervous system," Journal of Immunology, vol. 177, no. 10, pp. 7242-7249, 2006.

[91] M. L. Corcoran, W. G. Stetler-Stevenson, P. D. Brown, and L. M. Wahl, "Interleukin 4 inhibition of prostaglandin E2 synthesis blocks interstitial collagenase and 92-kDa type IV collagenase/ gelatinase production by human monocytes," Journal of Biological Chemistry, vol. 267, no. 1, pp. 515-519, 1992.

[92] F. E. Arthur, R. R. Shivers, and P. D. Bowman, "Astrocytemediated induction of tight junctions in brain capillary endothelium: an efficient in vitro model," Brain Research, vol. 433, no. 1, pp. 155-159, 1987.

[93] N. Malik, B. W. Greenfield, A. F. Wahl, and P. A. Kiener, "Activation of human monocytes through CD40 induces matrix metalloproteinases," Journal of Immunology, vol. 156, no. 10, pp. 3952-3960, 1996.

[94] H. Zhou, E. J. Bernhard, F. E. Fox, and P. C. Billings, "Induction of metalloproteinase activity in human T-lymphocytes," Biochimica et Biophysica Acta, vol. 1177, no. 2, pp. 174-178, 1993.

[95] K. A. C. Harkness, P. Adamson, J. D. Sussman, G. A. B. DaviesJones, J. Greenwood, and M. N. Woodroofe, "Dexamethasone regulation of matrix metalloproteinase expression in CNS vascular endothelium," Brain, vol. 123, part 4, pp. 698-709, 2000.

[96] T. Owens, T. Renno, V. Taupin, and M. Krakowski, "Inflammatory cytokines in the brain: does the CNS shape immune responses?" Immunology Today, vol. 15, no. 12, pp. 566-571, 1994.

[97] G. Opdenakker, S. Masure, B. Grillet, and J. van Damme, "Cytokine-mediated regulation of human leukocyte gelatinases and role in arthritis," Lymphokine and Cytokine Research, vol. 10, no. 4, pp. 317-324, 1991. 
[98] G. Opdenakker, S. Masure, P. Proost, A. Billiau, and J. van Damme, "Natural human monocyte gelatinase and its inhibitor," FEBS Letters, vol. 284, no. 1, pp. 73-78, 1991.

[99] R. N. Johnatty, D. D. Taub, S. P. Reeder et al., "Cytokine and chemokine regulation of proMMP-9 and TIMP-1 production by human peripheral blood lymphocytes," Journal of Immunology, vol. 158 , no. 5, pp. 2327-2333, 1997.

[100] D. Leppert, S. L. Hauser, J. L. Kishiyama, S. An, L. Zeng, and E. J. Goetzl, "Stimulation of matrix metalloproteinase-dependent migration of T cells by eicosanoids," FASEB Journal, vol. 9, no. 14, pp. 1473-1481, 1995.

[101] I. A. Schrijver, M. J. Melief, H. M. Markusse et al., "Peptidoglycan from sterile human spleen induces T-cell proliferation and inflammatory mediators in rheumatoid arthritis patients and healthy subjects," Rheumatology, vol. 40, no. 4, pp. 438-446, 2001.

[102] P. E. Gottschall and X. Yu, "Cytokines regulate gelatinase A and B (matrix metalloproteinase 2 and 9) activity in cultured rat astrocytes," Journal of Neurochemistry, vol. 64, no. 4, pp. 15131520, 1995.

[103] P. E. Gottschall, X. Yu, and B. Bing, "Increased production of gelatinase B (matrix metalloproteinase-9) and interleukin-6 by activated rat microglia in culture," Journal of Neuroscience Research, vol. 42, no. 3, pp. 335-342, 1995.

[104] G. M. Liuzzi, T. Latronico, A. Fasano, G. Carlone, and P. Riccio, "Interferon-beta inhibits the expression of metalloproteinases in rat glial cell cultures: implications for multiple sclerosis pathogenesis and treatment," Multiple Sclerosis, vol. 10, no. 3, pp. 290-297, 2004.

[105] Z. Ma, H. Qin, and E. N. Benveniste, “Transcriptional suppression of matrix metalloproteinase- 9 gene expression by IFN- $\gamma$ and IFN- $\beta$ : critical role of STAT-1 $\alpha$," Journal of Immunology, vol. 167, no. 9, pp. 5150-5159, 2001.

[106] J. Sancéau, D. D. Boyd, M. Seiki, and B. Bauvois, "Interferons inhibit tumor necrosis factor- $\alpha$-mediated matrix metalloproteinase- 9 activation via interferon regulatory factor-1 binding competition with NF- $\kappa \mathrm{B}$," Journal of Biological Chemistry, vol. 277, no. 38, pp. 35766-35775, 2002.

[107] M. L. Cuzner and G. Opdenakker, "Plasminogen activators and matrix metalloproteases, mediators of extracellular proteolysis in inflammatory demyelination of the central nervous system," Journal of Neuroimmunology, vol. 94, no. 1-2, pp. 1-14, 1999.

[108] O. Stuve Dooley NP, N. P. Dooley, J. H. Uhm et al., "Interferon beta- $1 \mathrm{~b}$ decreases the migration of $\mathrm{T}$ lymphocytes in vitro: effects on matrix metalloproteinase-9," Annals of Neurology, vol. 40, no. 6, pp. 853-863, 1996.

[109] E. J. Bartholomé, I. van Aelst, E. Koyen et al., "Human monocyte-derived dendritic cells produce bioactive gelatinase B: inhibition by IFN-beta," Journal of Interferon \& Cytokine Research, vol. 21, no. 7, pp. 495-501, 2001.

[110] M. Trojano, C. Avolio, G. M. Liuzzi et al., "Changes of serum sICAM-1 and MMP-9 induced by $\operatorname{rIFN} \beta-1 b$ treatment in relapsing-remitting MS," Neurology, vol. 53, no. 7, pp. 1402-1408, 1999.

[111] V. Ozenci Kouwenhoven M, N. Teleshova, M. Pashenkov, S. Fredrikson, and H. Link, "Multiple sclerosis: pro- and antiinflammatory cytokines and metalloproteinases are affected differentially by treatment with IFN-beta," Journal of Neuroimmunology, vol. 108, no. 1, pp. 236-243, 2000.

[112] S. Shapiro, Y. Shoenfeld, B. Gilburd, E. Sobel, and N. Lahat, "Intravenous gamma globulin inhibits the production of matrix metalloproteinase-9 in macrophages," Cancer, vol. 95, no. 9, pp. 2032-2037, 2002.

[113] C. Vaillant, M. Didier-Bazès, A. Hutter, M. F. Belin, and N. Thomasset, "Spatiotemporal expression patterns of metalloproteinases and their inhibitors in the postnatal developing rat cerebellum," Journal of Neuroscience, vol. 19, no. 12, pp. 49945004, 1999.

[114] R. C. Soler, Y. H. Gui, K. K. Linask, and R. J. Muschel, "MMP-9 (gelatinase B) mRNA is expressed during mouse neurogenesis and may be associated with vascularization," Developmental Brain Research, vol. 88, no. 1, pp. 37-52, 1995.

[115] J. H. Uhm, N. P. Dooley, L. Y. Oh, and V. W. Yong, "Oligodendrocytes utilize a matrix metalloproteinase, MMP-9, to extend processes along an astrocyte extracellular matrix," Glia, vol. 22, no. 1, pp. 53-63, 1998.

[116] L. Y. S. Oh, P. H. Larsen, C. A. Krekoski et al., "Matrix metalloproteinase-9/gelatinase B is required for process outgrowth by oligoclendrocytes," Journal of Neuroscience, vol. 19, no. 19, pp. 8464-8475, 1999.

[117] F. Yu, H. Kamada, K. Niizuma, H. Endo, and P. H. Chan, "Induction of MMP-9 expression and endothelial injury by oxidative stress after spinal cord injury," Journal of Neurotrauma, vol. 25, no. 3, pp. 184-195, 2008.

[118] A. Buss Pech K, B. A. Kakulas, D. Martin, J. Schoenen, J. Noth, and G. A. Brook, "Matrix metalloproteinases and their inhibitors in human traumatic spinal cord injury," $\mathrm{BMC} \mathrm{Neu-}$ rology, vol. 7, article 17, 2007.

[119] P. H. Larsen, J. E. Wells, W. B. Stallcup, G. Opdenakker, and V. W. Yong, "Matrix metalloproteinase-9 facilitates remyelination in part by processing the inhibitory NG2 proteoglycan," Journal of Neuroscience, vol. 23, no. 35, pp. 11127-11135, 2003.

[120] P. H. Larsen and V. W. Yong, "The expression of matrix metalloproteinase-12 by oligodendrocytes regulates their maturation and morphological differentiation," Journal of Neuroscience, vol. 24, no. 35, pp. 7597-7603, 2004.

[121] P. H. Larsen, A. G. DaSilva, K. Conant, and V. W. Yong, "Myelin formation during development of the CNS is delayed in matrix metalloproteinase- 9 and -12 null mice," Journal of Neuroscience, vol. 26, no. 8, pp. 2207-2214, 2006.

[122] J. Y. C. Hsu, R. McKeon, S. Goussev et al., "Matrix metalloproteinase-2 facilitates wound healing events that promote functional recovery after spinal cord injury," Journal of Neuroscience, vol. 26, no. 39, pp. 9841-9850, 2006.

[123] J. Haorah, S. H. Ramirez, K. Schall, D. Smith, R. Pandya, and Y. Persidsky, "Oxidative stress activates protein tyrosine kinase and matrix metalloproteinases leading to blood-brain barrier dysfunction," Journal of Neurochemistry, vol. 101, no. 2, pp. 566576, 2007.

[124] B. Luckow, J. Joergensen, S. Chilla et al., "Reduced intragraft mRNA expression of matrix metalloproteinases Mmp3, Mmp12, Mmp13 and Adam8, and diminished transplant arteriosclerosis in Ccr5-deficient mice," European Journal of Immunology, vol. 34, no. 9, pp. 2568-2578, 2004.

[125] M. S. Woo, J. S. Park, I. Y. Choi, W. K. Kimf, and H. S. Kim, "Inhibition of MMP-3 or -9 suppresses lipopolysaccharideinduced expression of proinflammatory cytokines and iNOS in microglia," Journal of Neurochemistry, vol. 106, no. 2, pp. 770780, 2008.

[126] H. Lassmann, F. Zimprich, K. Vass, and W. F. Hickey, "Microglial cells are a component of the perivascular glia limitans," Journal of Neuroscience Research, vol. 28, no. 2, pp. 236-243, 1991. 
[127] I. M. Ethell and D. W. Ethell, "Matrix metalloproteinases in brain development and remodeling: synaptic functions and targets," Journal of Neuroscience Research, vol. 85, no. 13, pp. 2813-2823, 2007.

[128] V. Nagy Bozdagi O, O. Bozdagi, O. Bozdagi et al., "Matrix metalloproteinase- 9 is required for hippocampal late-phase longterm potentiation and memory," Journal of Neuroscience, vol. 26, no. 7, pp. 1923-1934, 2006.

[129] E. C. Holland, "Glioblastoma multiforme: the terminator," Proceedings of the National Academy of Sciences, vol. 97, no. 12, pp. 6242-6244, 2000.

[130] K. Takakura, H. Abe, and R. Tanaka, "Effects of ACNU and radiotherapy on malignant glioma," Journal of Neurosurgery, vol. 64, no. 1, pp. 53-57, 1986.

[131] W. R. Shapiro, S. B. Green, P. C. Burger et al., "A randomized comparison of intra-arterial versus intravenous BCNU, with or without intravenous 5-fluorouracil, for newly diagnosed patients with malignant glioma," Journal of Neurosurgery, vol. 76, no. 5, pp. 772-781, 1992.

[132] R. Stupp, W. P. Mason, M. J. van den Bent et al., "Radiotherapy plus concomitant and adjuvant temozolomide for glioblastoma," New England Journal of Medicine, vol. 352, no. 10, pp. 987-996, 2005.

[133] E. G. van Meir, C. G. Hadjipanayis, A. D. Norden, H. K. Shu, P. Y. Wen, and J. J. Olson, "Exciting new advances in neurooncology: the avenue to a cure for malignant glioma," $C A$ Cancer Journal for Clinicians, vol. 60, no. 3, pp. 166-193, 2010.

[134] P. Rio-hortega, "Sobre la fagocitosis en los tumores y en otros procesos patológicos/P. del Río-Hortega," Archivos de Cardiología y Hematología, vol. 2, no. 5, pp. 161-220, 1921.

[135] M. B. Graeber, B. W. Scheithauer, and G. W. Kreutzberg, "Microglia in brain tumors," GLIA, vol. 40, no. 2, pp. 252-259, 2002.

[136] B. Badie and J. Schartner, "Role of microglia in glioma biology," Microscopy Research and Technique, vol. 54, no. 2, pp. 106-113, 2001.

[137] E. Ribot, A. K. Bouzier-Sore, V. Bouchaud et al., "Microglia used as vehicles for both inducible thymidine kinase gene therapy and MRI contrast agents for glioma therapy," Cancer Gene Therapy, vol. 14, no. 8, pp. 724-737, 2007.

[138] D. S. Markovic, K. Vinnakota, S. Chirasani et al., "Gliomas induce and exploit microglial MT1-MMP expression for tumor expansion," Proceedings of the National Academy of Sciences of the United States of America, vol. 106, no. 30, pp. 12530-12535, 2009.

[139] D. S. Markovic, R. Glass, M. Synowitz, N. van Rooijen, and H. Kettenmann, "Microglia stimulate the invasiveness of glioma cells by increasing the activity of metalloprotease-2," Journal of Neuropathology and Experimental Neurology, vol. 64, no. 9, pp. 754-762, 2005.

[140] J. J. Watters, J. M. Schartner, and B. Badie, "Microglia function in brain tumors," Journal of Neuroscience Research, vol. 81, no. 3 , pp. 447-455, 2005.

[141] M. Kerber, Y. Reiss, A. Wickersheim et al., "Flt-1 signaling in macrophages promotes glioma growth in vivo," Cancer Research, vol. 68, no. 18, pp. 7342-7351, 2008.

[142] H. Zhai, F. L. Heppner, and S. E. Tsirka, "Microglia/macrophages promote glioma progression," GLIA, vol. 59, no. 3, pp. 472-485, 2011.

[143] M. Sliwa, D. Markovic, K. Gabrusiewicz et al., "The invasion promoting effect of microglia on glioblastoma cells is inhibited by cyclosporin A," Brain, vol. 130, no. 2, pp. 476-489, 2007.
[144] W. P. Grasbon-Frodl EMFA, W. E. F. Klinkert, G. W. Kreutzberg, and M. B. Graeber, Jahrestagung der Neuroonkologischen Arbeitsgemeinschaft der Deutschen Gesellschaft fuer Neurochirurgie in Dresden, 1998.

[145] C. Huettner, S. Czub, S. Kerkau, W. Roggendorf, and J. C. Tonn, "Interleukin 10 is expressed in human gliomas in vivo and increases glioma cell proliferation and motility in vitro," Anticancer Research, vol. 17, no. 5 A, pp. 3217-3224, 1997.

[146] S. Wagner, S. Czub, M. Greif et al., "Microglial/macrophage expression of interleukin 10 in human glioblastomas," International Journal of Cancer, vol. 82, no. 1, pp. 12-16, 1999.

[147] K. Frei, C. Siepl, P. Groscurth, S. Bodmer, C. Schwerdel, and A. Fontana, "Antigen presentation and tumor cytotoxicity by interferon- $\gamma$-treated microglial cells," European Journal of Immunology, vol. 17, no. 9, pp. 1271-1278, 1987.

[148] A. Sutter, A. Hekmat, and G. A. Luckenbach, "Antibodymediated tumor cytotoxicity of microglia," Pathobiology, vol. 59, no. 4, pp. 254-258, 1991.

[149] P. Voisin, V. Bouchaud, M. Merle et al., "Microglia in close vicinity of glioma cells: correlation between phenotype and metabolic alterations," Frontiers in Neuroenergetics, vol. 2, article 131, 2010.

[150] S. F. Hussain, D. Yang, D. Suki, K. Aldape, E. Grimm, and A. B. Heimberger, "The role of human glioma-infiltrating microglia/ macrophages in mediating antitumor immune responses," Neuro-Oncology, vol. 8, no. 3, pp. 261-279, 2006.

[151] J. S. Rao, "Molecular mechanisms of glioma invasiveness: the role of proteases," Nature Reviews Cancer, vol. 3, pp. 489-501, 2003.

[152] U. K. Hanisch and H. Kettenmann, "Microglia: active sensor and versatile effector cells in the normal and pathologic brain," Nature Neuroscience, vol. 10, no. 11, pp. 1387-1394, 2007.

[153] L. A. Liotta, K. Tryggvason, and S. Garbisa, "Metastatic potential correlates with enzymatic degradation of basement membrane collagen," Nature, vol. 284, no. 5751, pp. 67-68, 1980.

[154] M. Bjorklund and E. Koivunen, "Gelatinase-mediated migration and invasion of cancer cells," Biochimica et Biophysica Acta, vol. 1755, no. 1, pp. 37-69, 2005.

[155] B. Fingleton, "Matrix metalloproteinases: roles in cancer and metastasis," Frontiers in Bioscience, vol. 11, pp. 479-491, 2006.

[156] C. Colotti, V. Angeli, S. del Ry, M. Maltinti, S. Vittorini, and D. Giannessi, "Matrix metalloprotease- 2 and -9 concentration and activity in serum and culture medium samples: a methodological reappraisal," Clinical Chemistry and Laboratory Medicine, vol. 45, no. 10, pp. 1292-1298, 2007.

[157] S. Patel, G. Sumitra, B. C. Koner, and A. Saxena, "Role of serum matrix metalloproteinase- 2 and -9 to predict breast cancer progression," Clinical Biochemistry, vol. 44, no. 10-11, pp. 869872, 2011.

[158] T. Turpeenniemi-Hujanen, "Gelatinases (MMP-2 and -9) and their natural inhibitors as prognostic indicators in solid cancers," Biochimie, vol. 87, no. 3-4, pp. 287-297, 2005.

[159] L. Liu, J. Wu, Z. Ying et al., "Astrocyte elevated gene-1 upregulates matrix metalloproteinase- 9 and induces human glioma invasion," Cancer Research, vol. 70, no. 9, pp. 3750-3759, 2010.

[160] D. Sbardella, G. F. Fasciglione, M. Gioia et al., "Human matrix metalloproteinases: an ubiquitarian class of enzymes involved in several pathological processes," Molecular Aspects of Medicine, vol. 33, no. 2, pp. 119-208, 2012.

[161] L. Aresu, S. Benali, S. Garbisa, E. Gallo, and M. Castagnaro, "Matrix metalloproteinases and their role in the renal epithelial 
mesenchymal transition," Histology and Histopathology, vol. 26, no. 3, pp. 307-313, 2011.

[162] A. S. Ribeiro, A. Albergaria, B. Sousa et al., "Extracellular cleavage and shedding of P-cadherin: a mechanism underlying the invasive behaviour of breast cancer cells," Oncogene, vol. 29, no. 3, pp. 392-402, 2010.

[163] E. Levi, R. Fridman, H. Q. Miao, Y. S. Ma, A. Yayon, and I. Vlodavsky, "Matrix metalloproteinase 2 releases active soluble ectodomain of fibroblast growth factor receptor 1," Proceedings of the National Academy of Sciences, vol. 93, no. 14, pp. 70697074, 1996.

[164] C. S. Gondi, D. H. Dinh, J. D. Klopffenstein, M. Gujrati, and J. S. Rao, "MMP-2 downregulation mediates differential regulation of cell death via ErbB-2 in glioma xenografts," International Journal of Oncology, vol. 35, no. 2, pp. 257-263, 2009.

[165] A. V. Badiga, C. Chetty, D. Kesanakurti et al., "MMP-2 siRNA inhibits radiation-enhanced invasiveness in glioma cells," PLoS ONE, vol. 6, no. 6, Article ID e20614, 2011.

[166] Y. K. Jo, S. J. Park, J. H. Shin et al., "ARP101, a selective MMP2 inhibitor, induces autophagy-associated cell death in cancer cells," Biochemical and Biophysical Research Communications, vol. 404, no. 4, pp. 1039-1043, 2011.

[167] K. Lampert, U. Machein, M. R. Machein, W. Conca, H. H. Peter, and B. Volk, "Expression of matrix metalloproteinases and their tissue inhibitors in human brain tumors," American Journal of Pathology, vol. 153, no. 2, pp. 429-437, 1998.

[168] M. Yamamoto, S. Mohanam, R. Sawaya et al., "Differential expression of membrane-type matrix metalloproteinase and its correlation with gelatinase A activation in human malignant brain tumors in vivo and in vitro," Cancer Research, vol. 56, no. 2, pp. 384-392, 1996.

[169] P. A. Forsyth, H. Wong, T. D. Laing et al., "Gelatinase-A (MMP-2), gelatinase-B (MMP-9) and membrane type matrix metalloproteinase-1 (MT1-MMP) are involved in different aspects of the pathophysiology of malignant gliomas," British Journal of Cancer, vol. 79, no. 11-12, pp. 1828-1835, 1999.

[170] P. O. Estève, E. Chicoine, O. Robledo et al., "Protein kinase Czeta regulates transcription of the matrix metalloproteinase-9 gene induced by IL-1 and TNF-alpha in glioma cells via NFkappa B," Journal of Biological Chemistry, vol. 277, no. 38, pp. 35150-35155, 2002.

[171] J. S. Rao, M. Yamamoto, S. Mohaman et al., "Expression and localization of $92 \mathrm{kDa}$ type IV collagenase/gelatinase B (MMP9) in human gliomas," Clinical \& Experimental Metastasis, vol. 14, no. 1, pp. 12-18, 1996.

[172] P. Guo, Y. Imanishi, F. C. Cackowski et al., "Up-regulation of angiopoietin-2, matrix metalloprotease-2, membrane type 1 metalloprotease, and laminin 5 gamma 2 correlates with the invasiveness of human glioma," The American Journal of Pathology, vol. 166, no. 3, pp. 877-890, 2005.

[173] T. Yamada, Y. Yoshiyama, H. Sato, M. Seiki, A. Shinagawa, and M. Takahashi, "White matter microglia produce membranetype matrix metalloprotease, an activator of gelatinase $\mathrm{A}$, in human brain tissues," Acta Neuropathologica, vol. 90, no. 5, pp. 421-424, 1995.

[174] A. Ghosh and S. Chaudhuri, "Microglial action in glioma: a boon turns bane," Immunology Letters, vol. 131, no. 1, pp. 3-9, 2010.

[175] P. Wisniewski, A. Ellert-Miklaszewska, A. Kwiatkowska, and B. Kaminska, "Non-apoptotic Fas signaling regulates invasiveness of glioma cells and modulates MMP-2 activity via NF $\kappa$ B-TIMP2 pathway," Cellular Signalling, vol. 22, no. 2, pp. 212-220, 2010.
[176] F. Baumann, P. Leukel, A. Doerfelt et al., "Lactate promotes glioma migration by TGF- $\beta 2$-dependent regulation of matrix metalloproteinase-2," Neuro-Oncology, vol. 11, no. 4, pp. 368380, 2009.

[177] W. Wick, M. Platten, and M. Weller, "Glioma cell invasion: regulation of metalloproteinase activity by TGF- $\beta$," Journal of Neuro-Oncology, vol. 53, no. 2, pp. 177-185, 2001.

[178] A. Nakao, T. Imamura, S. Souchelnytskyi et al., "TGF$\beta$ receptor-mediated signalling through $\operatorname{Smad} 2, \operatorname{Smad} 3$ and Smad4," EMBO Journal, vol. 16, no. 17, pp. 5353-5362, 1997.

[179] K. Imai, A. Hiramatsu, D. Fukushima, M. D. Pierschbacher, and Y. Okada, "Degradation of decorin by matrix metalloproteinases: identification of the cleavage sites, kinetic analyses and transforming growth factor- $\beta 1$ release," Biochemical Journal, vol. 322, part 3, pp. 809-814, 1997.

[180] Q. Yu and I. Stamenkovic, "Cell surface-localized matrix metalloproteinase- 9 proteolytically activates TGF- $\beta$ and promotes tumor invasion and angiogenesis," Genes and Development, vol. 14, no. 2, pp. 163-176, 2000.

[181] M. G. Binker, A. A. Binker-Cosen, H. Y. Gaisano, R. H. de Cosen, and L. I. Cosen-Binker, "TGF- $\beta 1$ increases invasiveness of SW1990 cells through Rac1/ROS/NF- $\kappa$ B/IL-6/MMP-2," Biochemical and Biophysical Research Communications, vol. 405, no. 1, pp. 140-145, 2011.

[182] E. S. Kim, Y. W. Sohn, and A. Moon, “TGF- $\beta$-induced transcriptional activation of MMP-2 is mediated by activating transcription factor (ATF)2 in human breast epithelial cells," Cancer Letters, vol. 252, no. 1, pp. 147-156, 2007.

[183] A. Dasgupta, B. Raychaudhuri, T. Haqqi et al., "Stat3 activation is required for the growth of U87 cell-derived tumours in mice," European Journal of Cancer, vol. 45, no. 4, pp. 677-684, 2009.

[184] H. W. Lo, X. Cao, H. Zhu, and F. Ali-Osman, "Constitutively activated STAT3 frequently coexpresses with epidermal growth factor receptor in high-grade gliomas and targeting STAT3 sensitizes them to iressa and alkylators," Clinical Cancer Research, vol. 14, no. 19, pp. 6042-6054, 2008.

[185] M. Mizoguchi, R. A. Betensky, T. T. Batchelor, D. C. Bernay, D. N. Louis, and C. L. Nutt, "Activation of STAT3, MAPK, and AKT in malignant astrocytic gliomas: correlation with EGFR status, tumor grade, and survival," Journal of Neuropathology and Experimental Neurology, vol. 65, no. 12, pp. 1181-1188, 2006.

[186] S. O. Rahaman, P. C. Harbor, O. Chernova, G. H. Barnett, M. A. Vogelbaum, and S. J. Haque, "Inhibition of constitutively active Stat 3 suppresses proliferation and induces apoptosis in glioblastoma multiforme cells," Oncogene, vol. 21, no. 55, pp. 8404-8413, 2002.

[187] L. K. Schaefer, Z. Ren, G. N. Fuller, and T. S. Schaefer, "Constitutive of Stat $3 \alpha$ in brain tumors: localization to tumor endothelial cells and activation by the endothelial tyrosine kinase receptor (VEGFR-2)," Oncogene, vol. 21, no. 13, pp. 20582065, 2002.

[188] S. H. Chen, G. Y. Gillespie, and E. N. Benveniste, "Divergent effects of oncostatin $\mathrm{M}$ on astroglioma cells: influence on cell proliferation, invasion, and expression of matrix metalloproteinases," GLIA, vol. 53, no. 2, pp. 191-200, 2006.

[189] P. Repovic, C. Y. Fears, C. L. Gladson, and E. N. Benveniste, "Oncostatin-M induction of vascular endothelial growth factor expression in astroglioma cells," Oncogene, vol. 22, no. 50, pp. 8117-8124, 2003.

[190] J. Held-Feindt, K. Hattermann, S. S. Müerköster et al., "CX3CR1 promotes recruitment of human glioma-infiltrating 
microglia/macrophages (GIMs)," Experimental Cell Research, vol. 316, no. 9, pp. 1553-1566, 2010.

[191] R. Yabkowitz, S. Meyer, T. Black, G. Elliott, L. A. Merewether, and H. K. Yamane, "Inflammatory cytokines and vascular endothelial growth factor stimulate the release of soluble tie receptor from human endothelial cells via metalloprotease activation," Blood, vol. 93, no. 6, pp. 1969-1979, 1999.

[192] H. Wang, J. D. Lathia, Q. Wu et al., "Targeting interleukin 6 signaling suppresses glioma stem cell survival and tumor growth," Stem Cells, vol. 27, no. 10, pp. 2393-2404, 2009.

[193] R. Li, G. Li, L. Deng et al., "IL-6 augments the invasiveness of U87MG human glioblastoma multiforme cells via upregulation of MMP-2 and fascin-1," Oncology Reports, vol. 23, no. 6, pp. 1553-1559, 2010.

[194] J. B. Johnston, C. Silva, G. Gonzalez et al., "Diminished adenosine A1 receptor expression on macrophages in brain and blood of patients with multiple sclerosis," Annals of Neurology, vol. 49, no. 5, pp. 650-658, 2001.

[195] S. Tsutsui, J. Schnermann, F. Noorbakhsh et al., "A1 Adenosine Receptor Upregulation and Activation Attenuates Neuroinflammation and Demyelination in a Model of Multiple Sclerosis," Journal of Neuroscience, vol. 24, no. 6, pp. 1521-1529, 2004.

[196] A. Beliveau, J. D. Mott, A. Lo et al., "Raf-induced MMP9 disrupts tissue architecture of human breast cells in three-dimensional culture and is necessary for tumor growth in vivo," Genes and Development, vol. 24, no. 24, pp. 2800-2811, 2010.

[197] C. C. Lin, C. T. Kuob, C. Y. Cheng et al., "IL-1 $\beta$ promotes A549 cell migration via MAPKs/AP-1- and NF- $\kappa$ B-dependent matrix metalloproteinase-9 expression," Cellular Signalling, vol. 21, no. 11, pp. 1652-1662, 2009.

[198] V. J. Coulson-Thomas, T. F. Gesteira, Y. M. Coulson-Thomas et al., "Fibroblast and prostate tumor cell cross-talk: fibroblast differentiation, TGF- $\beta$, and extracellular matrix down-regulation," Experimental Cell Research, vol. 316, no. 19, pp. 3207-3226, 2010.

[199] B. Kumar, S. Koul, J. Petersen et al., "p38 mitogen-activated protein kinase-driven MAPKAPK2 regulates invasion of bladder cancer by modulation of MMP-2 and MMP-9 activity," Cancer Research, vol. 70, no. 2, pp. 832-841, 2010.

[200] P. Ehrenfeld, I. Conejeros, M. F. Pavicic et al., "Activation of kinin $\mathrm{B} 1$ receptor increases the release of metalloproteases- 2 and -9 from both estrogen-sensitive and -insensitive breast cancer cells," Cancer Letters, vol. 301, no. 1, pp. 106-118, 2011.

[201] J. Oh, R. Takahashi, S. Kondo et al., "The membrane-anchored MMP inhibitor RECK is a key regulator of extracellular matrix integrity and angiogenesis," Cell, vol. 107, no. 6, pp. 789-800, 2001.

[202] L. M. Coussens, B. Fingleton, and L. M. Matrisian, "Matrix metalloproteinase inhibitors and cancer: trials and tribulations," Science, vol. 295, no. 5564, pp. 2387-2392, 2002.

[203] C. M. Overall and C. López-Otín, "Strategies for MMP inhibition in cancer: innovations for the post-trial era," Nature Reviews Cancer, vol. 2, no. 9, pp. 657-672, 2002. 


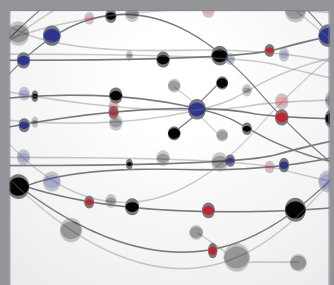

The Scientific World Journal
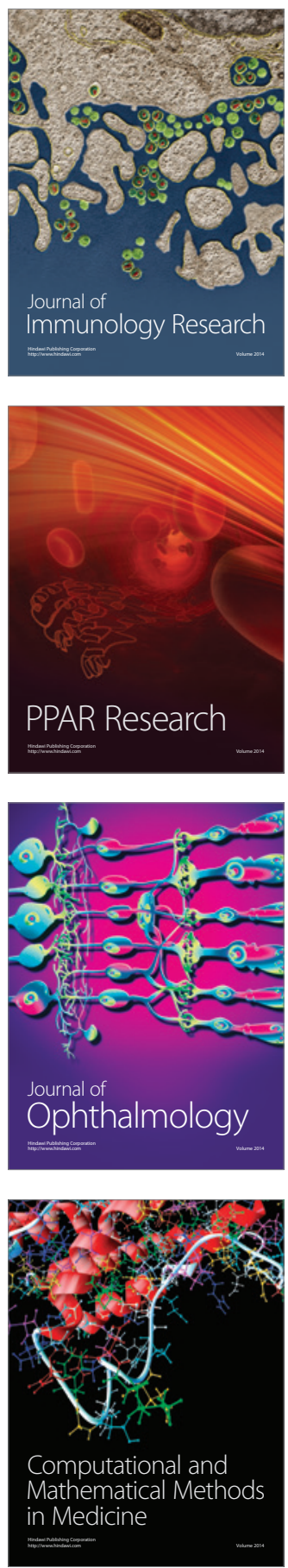

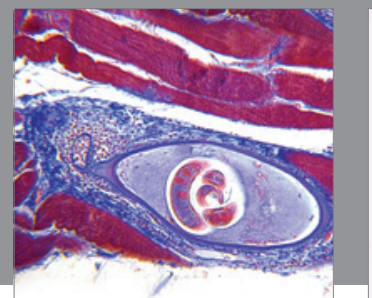

Gastroenterology

Research and Practice
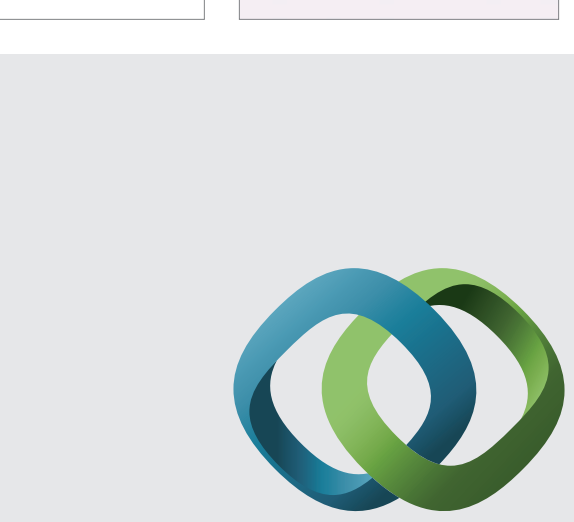

\section{Hindawi}

Submit your manuscripts at

http://www.hindawi.com
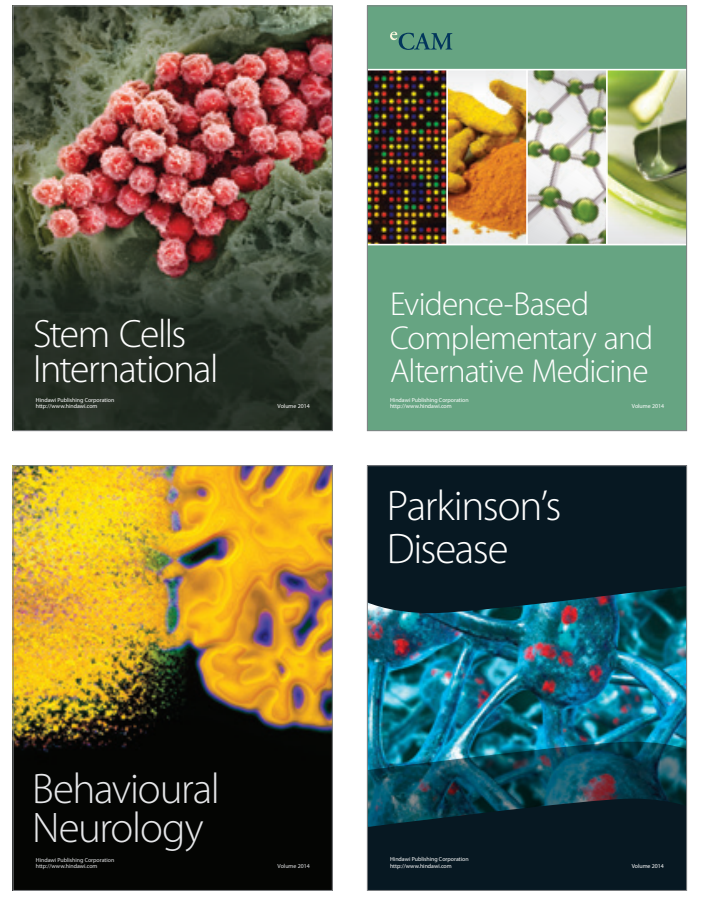
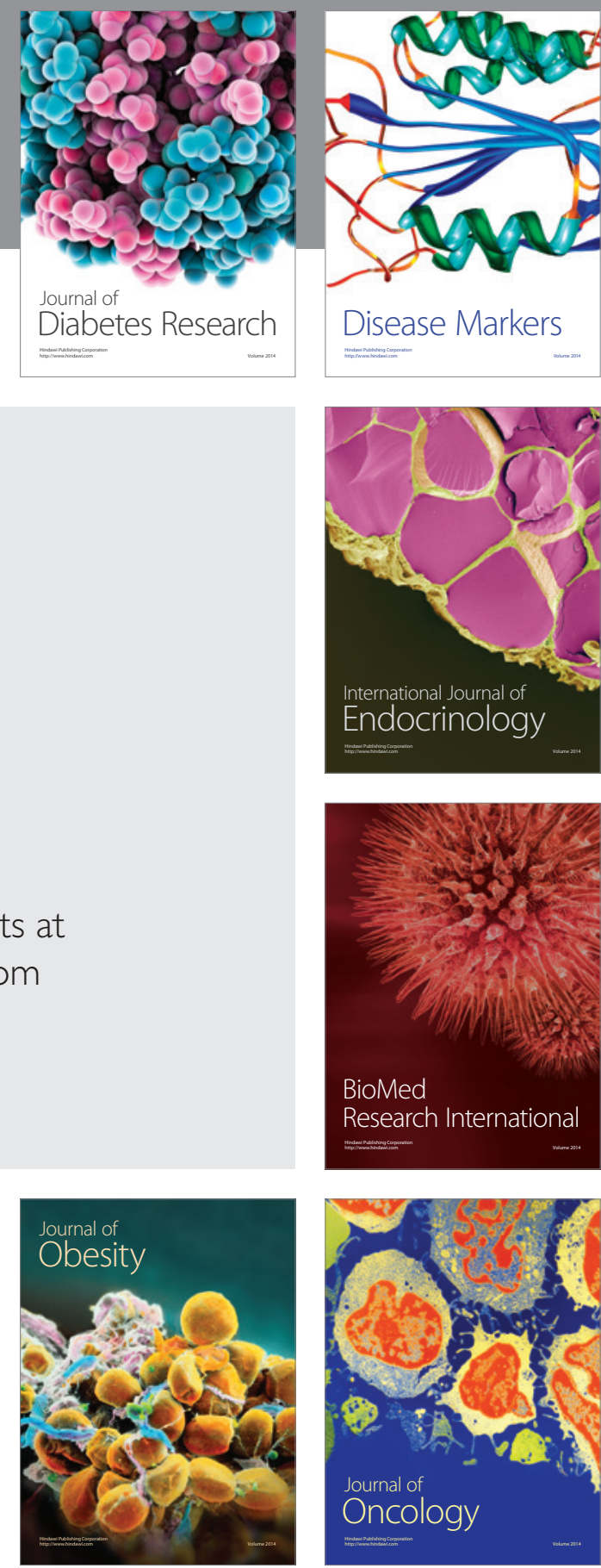

Disease Markers
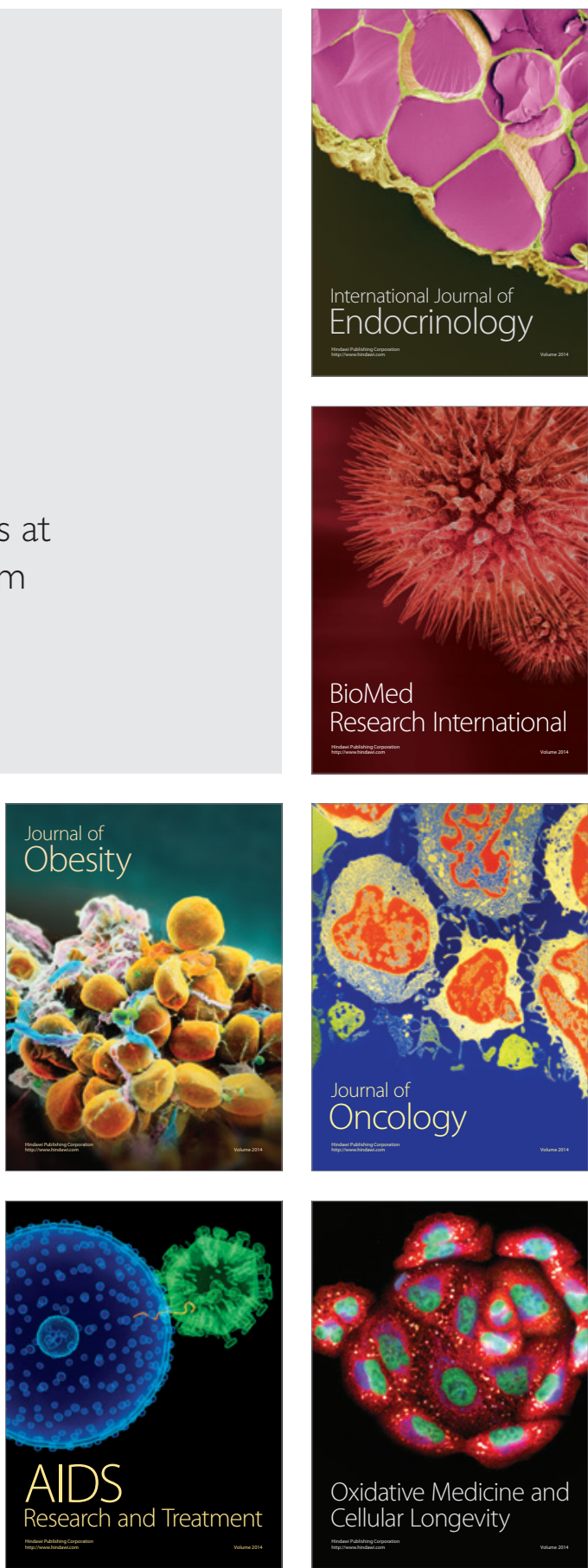